Portland State University

PDXScholar

Dissertations and Theses

Dissertations and Theses

Spring 6-8-2017

\title{
Analyzing Dam Feasibility in the Willamette River Watershed
}

Alexander Cameron Nagel

Portland State University

Follow this and additional works at: https://pdxscholar.library.pdx.edu/open_access_etds

Part of the Geography Commons, Hydrology Commons, and the Water Resource Management Commons

Let us know how access to this document benefits you.

\section{Recommended Citation}

Nagel, Alexander Cameron, "Analyzing Dam Feasibility in the Willamette River Watershed" (2017).

Dissertations and Theses. Paper 4012.

https://doi.org/10.15760/etd.5896

This Thesis is brought to you for free and open access. It has been accepted for inclusion in Dissertations and Theses by an authorized administrator of PDXScholar. Please contact us if we can make this document more accessible: pdxscholar@pdx.edu. 
Analyzing Dam Feasibility in the Willamette River Watershed

by

Alexander Cameron Nagel

A thesis submitted in partial fulfillment of the requirements for the degree of

\author{
Master of Science \\ in \\ Geography \\ Thesis Committee: \\ Heejun Chang, Chair \\ Geoffrey Duh \\ Paul Loikith
}

Portland State University

2017 


\begin{abstract}
This study conducts a dam-scale cost versus benefit analysis in order to explore the feasibility of each the 13 U.S. Army Corps of Engineers (USACE) commissioned dams in Oregon's Willamette River network. Constructed between 1941 and 1969, these structures function in collaboration to comprise the Willamette River Basin Reservoir System (WRBRS). The motivation for this project derives from a growing awareness of the biophysical impacts that dam structures can have on riparian habitats. This project compares each of the 13 dams being assessed, to prioritize their level of utility within the system. The study takes the metrics from the top three services (flood regulation, hydropower generation and recreation) and disservices (fish mortality, structural risk and water temperature hazards) and creates a rubric that scores the feasibility of each dam within the system. Within a range between 0 to 3 for three dam services and 0 to -4.5 for two disservices, the overall calculated score elucidates for each structure whether its contribution to the WRBRS is positive or negative.

Further analysis searches for spatiotemporal trends such as anomalous tributaries or magnified structural risk for structures exceeding a certain age. GIS data from the National Inventory of Dams (NID), U.S. Geologic Survey (USGS) water measurements, raw data from USACE, and peer-reviewed studies comprise the statistics that generate results for this analysis. The computed scores for each dam yield an average overall score of -1.31 , and nine of the 13 structures have negative results, indicating that the WRBRS faces challenges going forward. The study seeks to contribute to the increasingly relevant examination of dam networks at the watershed scale.
\end{abstract}




\section{Acknowledgements}

I would like to sincerely thank Professor Heejun Chang for advising, mentoring,

and contributing significant feedback to this project. My gratitude to Professor Geoffrey

Duh and Professor Paul Loikith for their role as committee members and their insight

during the proposal stage. I want to thank Barbara Brower and my fellow cohorts, who

helped me navigate the initial phases of this process in Research Design. Also, thanks to

Adam Mosbrucker and Steven Sobieszcyk, for their compelling classes that inspired my

decision to focus on Hydrologic science for this thesis project. Finally, I want to express

my appreciation to the PSU Geography Department for providing a great opportunity to

pursue my academic interests, and the tools to succeed at the graduate level. 


\section{Table of Contents}

Abstract....

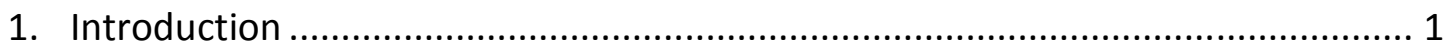

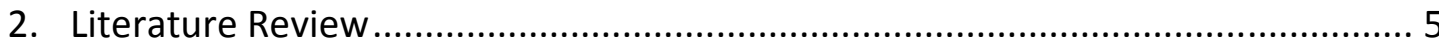

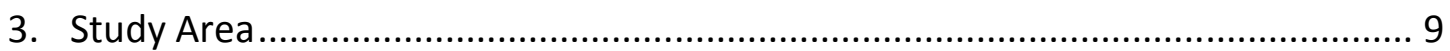

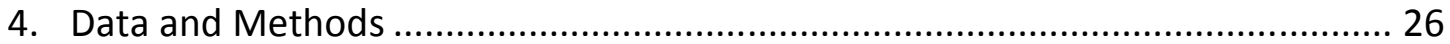

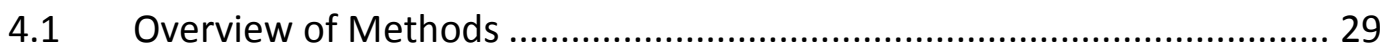

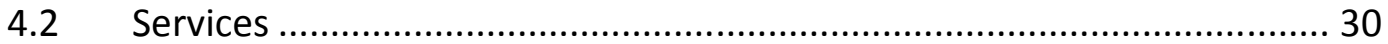

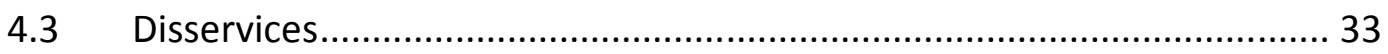

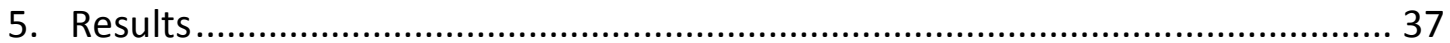

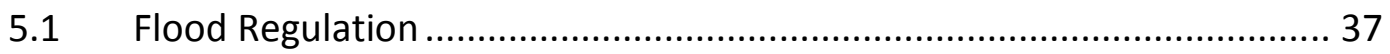

$5.2 \quad$ Hydropower Generation .................................................................. 39

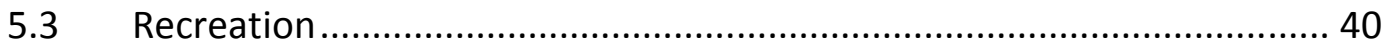

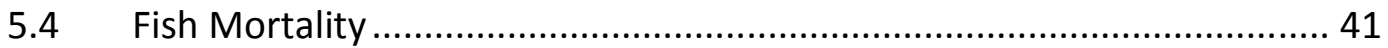

$5.5 \quad$ Water Temperature Hazards ........................................................... 42

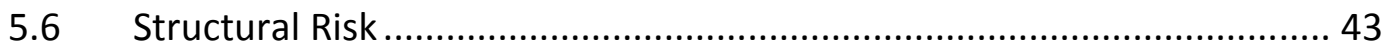

5.7 Synthesis of Overall Service Levels ....................................................... 44

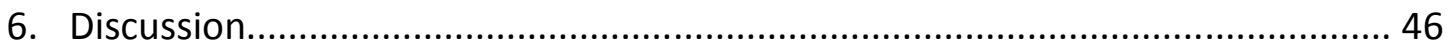

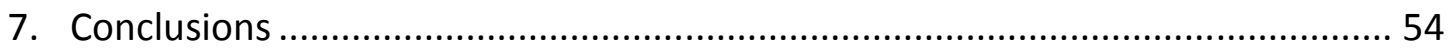

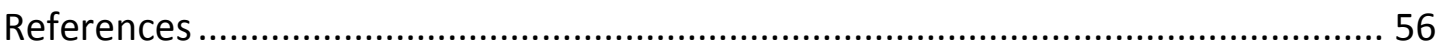




\section{List of Tables}

Table Name

1. Overview of Academic Studies Related to WRBRS Analysis

2. Characteristics of WBRS Dams

3. Decision-Based Support System Outline for Dam Managers

4. Data Source Information for Services and Disservices

5. Data for Criteria \#1: Flood Regulation (Service)

6. Data for Criteria \#2: Hydropower Generation (Service)

7. Data for Criteria \#3: Recreation (Service)

8. Data for Criteria \#4: Fish Mortality (Disservice)

9. Data for Criteria \#6: Water Temperature Hazards (Disservice)

10. Data for Control Variable: Structural Risk

11. Data for Overall Rubric Scores
Page Number 


\section{List of Figures}

Figure Name

Page Number

1. Map of Willamette Basin Reservoir System (WRBRS) Dams 9

2.1. Spider Graph for Big Cliff Dam 48

2.2. Spider Graph for Blue River Dam 48

2.3. Spider Graph for Cottage Grove Dam $\quad 48$

2.4. Spider Graph for Cougar Dam 48

2.5. Spider Graph for Detroit Dam 49

2.6. Spider Graph for Dexter Dam 49

2.7. Spider Graph for Dorena Dam 49

2.8. Spider Graph for Fall Creek Dam 49

2.9. Spider Graph for Fern Ridge Dam 50

2.10. Spider Graph for Foster Dam 50

2.11. Spider Graph for Green Peter Dam 50

2.12. Spider Graph for Hills Creek Dam 50

2.13. Spider Graph for Lookout Point Dam 51

2.14. Spider Graph for Overall Criteria Rubric Scores 51 
Chapter 1: Introduction

Dams in the United States date back to the early $19^{\text {th }}$ century, as obstructions of river channels were discovered to provide benefits such as water storage, flood regulation and ultimately hydroelectricity generation. The scale to which these modifications were performed, however, was limited to small tributaries or streams and used for site specific purposes such as powering a mill or maintaining water supply during summer droughts (American Rivers, 2010). Successes in this practice compelled innovation that ran parallel with the trajectory of industrialization in the U.S. Originally wooden or earthen, fill structures were supplanted by concrete and steel, which allowed larger rivers to be harnessed and their energies exploited. During the $20^{\text {th }}$ century, the western U.S. saw unprecedented levels of population growth and settlement expansion into areas formerly uninhabitable, transformed by massive water diversion projects to facilitate arid communities (Reisner, 1996). Large impoundments, driven by the U.S. Bureau of Reclamation (USBR) were instrumental in supporting rising demand on consistent water availability, meanwhile creating recreational opportunities, mitigating flooding and providing employment during an era of prodigious infrastructural investment (Wilkinson, 1996).

As time went on, large dams became not only physically embedded in formerly unaltered environments, but also were regarded as icons of American ingenuity. By the 1970 s, when environmentalism began to gain national momentum, more than 80,000 dams larger than 15-meters high had been constructed on more than two-thirds of the nations' waterways (Rosenberg, 2000). These architectural marvels, although 
institutionalized and responsible for lucrative economic activities were perceived with skepticism by certain corners of scientific and environmental communities (Wilkinson, 1992). The momentum of dam building continued with little impediment until viable sites for structures had been predominately filled (Nikiforuk, 2016). By the end of the $20^{\text {th }}$ century, a complex web of dam regulations, administrative bodies and associated stakeholders had developed so that any attempt at carrying out a removal was met with factious disagreement and bureaucratic roadblocks. Nevertheless, biologic and hydrologic research has exposed that dam structures pose "direct impacts to the biological, chemical and physical properties of rivers and riparian environments" (American Rivers, 2010). Such studies have spearheaded the beginning of a transformation in which over 1,000 obsolete or harmful structures have been removed and their natural runoff restored (Magilligan, 2016).

Despite the growing body of knowledge that questions the costs versus benefits of dams, they inhabit an obdurate place in current dialogue surrounding the future of energy production. In an era in which the overwhelming global shift is away from fossil fuels in favor of renewable energy generation, dams are nebulous. News articles discuss solar and wind on a daily basis, yet overlook the substantial contribution that hydropower has on energy systems. This is likely because dams have been a component of the power grid for decades and are often taken for granted. That said, in 2015 "electricity generated by hydropower accounted for more than $85 \%$ of global renewable electricity generation" (IFPRI, 2017). Undoubtedly, dams will continue to have an important role in the global energy sector, not to mention the other services used to 
bolster their utility. Their omnipresence, however, is perceived as superfluous by a growing community of scholars and scientists aware of a shifting energy economy.

The United States dam infrastructure is at a crossroads because any infrastructure experiences wear and tear over time, "but the challenge today is the age of dams in the U.S. According to a 2015 Department of Energy report, 75\% of hydro capacity is at plants that are over 50 years old" (Hoium, 2017). In the Willamette Basin, the focus of this project, the age of the 13 structures are consistent with or exceeds the national average, which in general is approaching a tipping point, where ecological consequences and potential structural failure are beginning to outweigh the services that support continued dam commissioning (Branco, 2014). While the characteristics of each dam and watershed are unique, and understanding a system in depth requires site specific analysis, the growing body of scientific literature is integral in informing any dam related study for identifying successes and failures and the principal tools for assessing a dam or set of dams comprehensively. The current study applies this general framework and incorporates literature derived analysis methods to explore the questions:

(1) What are the current levels of services and disservices for the 13 WRBRS dams, based on a multi-variable scoring rubric?

(2) Based on the rubric results, are there certain structures that are especially beneficial or harmful to their surrounding habitats?

(3) After identifying the anomalous structures, what criteria are most important in determining the overall feasibility of the dam structures? 
The small number of removals thus far have been a vital component of comparing riparian habitats before and after channel alteration. Often explored are small scale shifts in channel gradient, sediment aggradation downstream upon sudden release, as well as fish re-habitation following reopening of upstream habitats (Cui, 2014). Underlying each of these issues, however, is the fundamental concept of weighing the services dams provide against the disservices caused as a byproduct. That has been the focal point of dam related literature and allows methods to be developed that can be applied to all rivers, despite their distinct qualities. 


\section{Chapter 2: Literature Review}

The framework for this project is inspired by hydrologic studies that apply a range of methods for analyzing dam feasibility, removal, and riparian habitats influenced by channel modification. For example, a series of studies apply a similar scope to this WRBRS project by evaluating a series of dams within a shared watershed (Branco, 2014; Pejchar, 2001; Kuby, 2005; Quiñones, 2015; Tomsic; 2007) (See Table 1.). One such study, on the Tagus River, models habitat suitability loss based on channel fragmentation to create a prioritized removal scenario (Branco, 2014). The author's methodology informs this project because it uses data collection that can be standardized and contrasted among structures to reveal geospatial trends.

Also, foundational to this analysis is a California dam survey of impacts on salmonids, based on variables related to habitat suitability under current conditions, and contrasted against simulated removals. The scoring rubric results format was adapted and individualized for this study, because it facilitates a system for weighing multiple criteria, positive and negative, equally to calculate a score that quantifies overall feasibility (Quiñones 2015).

Another paradigm for studying dams is to focus on a specific environmental byproduct and study this issue at one site, or among a series of dams. While this approach was not taken specifically for the WRBRS study, the depth of analysis was influential in deciding whether data for each criterion is sufficient for evaluation. One such example is a study of evolutionary changes in Salmon along channels hosting dams 
compared to free-flowing rivers (Angilletta, 2015). Factors that influence this notable impact are extrapolated and provide a guideline for determining WRBRS disservices.

The breadth of variables of the WRBRS study is focused on attempting to capture some of the foremost benefits and costs, while not excluding additional factors for future studies (Kuby, 2005). This type of analysis is used in studying dams broadly, so that results can be utilized for a diversity of purposes. Notably, a study of dam removal practicality uses a multi-objective portfolio analysis that incorporates data from a range of economic, environmental and social factors (Zheng 2013). Rather than attempt to approach dam analysis with a pre-determined agenda, this format of study is effective in that it focuses on comprehensive data collection, and limits ideological scrutiny in an effort to provide tools for other stakeholders (Pejchar and Warner, 2001).

Finally, the body of knowledge surrounding actual post-removal riparian habitat successions is growing as the more than 1,000 large dam removal projects are thoroughly documented and studied for a variety of issues that can be contrasted sitespecially based on pre-and post-undamming (American Rivers, 2010). Given the exorbitant expenditures required to carry out a dam decommissioning, and the threats facing a miscalculated project, the resources dedicated to removals are substantial and provide unique insight into the successes and failures in habitat recovery following removal. Studies range in scope and often look at channel geomorphic change or fish repopulation upstream (East, 2015). Importantly, there doesn't seems to be a direct link between structural risk and level of success in decommissioning. That said, as aging structures are analyzed seismically and architecturally, and may prove to be vulnerable 
in certain cases, having templates for removal projects with similar conditions can be a

valuable tool for determining whether to engage in a removal project or to restore and

continue managing a dam structure (Magilligan, 2016). The following table outlines

some of the prominent academic studies, some of which detailed above, that inspire the

framework and methodologies for this WRBRS analysis.

Table 1. Overview of Academic Studies Related to WRBRS Analysis

\begin{tabular}{|c|c|c|c|c|}
\hline $\begin{array}{r}\text { Author } \\
\text { (year) }\end{array}$ & Study Area & Analysis Period & $\begin{array}{l}\text { Data Collection/ } \\
\text { Methodology }\end{array}$ & Major Findings \\
\hline $\begin{array}{l}\text { Allen, } \\
\text { Richard } \\
\text { (2001) }\end{array}$ & $\begin{array}{l}\text { Columbia } \\
\text { River } \\
\text { watershed, } \\
\text { (Oregon, } \\
\text { Washington, } \\
\text { Idaho, } \\
\text { British } \\
\text { Columbia) }\end{array}$ & $\begin{array}{l}1976 \text { (following major } \\
\text { dam projects on } \\
\text { Columbia) - } 2001 \text {. }\end{array}$ & $\begin{array}{l}\text { Primarily annual } \\
\text { fish run numbers } \\
\text { from USACE, and } \\
\text { environmental } \\
\text { data from } \\
\text { management } \\
\text { bodies. }\end{array}$ & $\begin{array}{l}\text { Unless there is } \\
\text { investment in sufficient } \\
\text { fish passage on } \\
\text { mainstem Columbia } \\
\text { dams, other habitat } \\
\text { improvement projects } \\
\text { are a misallocation of } \\
\text { resources. }\end{array}$ \\
\hline $\begin{array}{r}\text { Angilletta } \\
\text { et al. } \\
(2008)\end{array}$ & $\begin{array}{l}\text { Four Oregon } \\
\text { Rivers } \\
\text { (Cowlitz, Fall } \\
\text { Creek, } \\
\text { Rogue, } \\
\text { Willamette), } \\
\text { Oregon }\end{array}$ & $\begin{array}{l}\text { Four parts: Historical } \\
\text { context (1910's - } \\
\text { present), temperature } \\
\text { impacts, physiological } \\
\text { performance, and } \\
\text { evolutionary response } \\
\text { (primarily 1990's- } \\
\text { 2008). }\end{array}$ & $\begin{array}{l}\text { USGS gaging } \\
\text { station and self- } \\
\text { collected below- } \\
\text { above dam } \\
\text { temperature } \\
\text { data. }\end{array}$ & $\begin{array}{l}\text { Unnatural stream } \\
\text { temperatures impact } \\
\text { Chinook Salmon health } \\
\text { and decreases fitness of } \\
\text { offspring. }\end{array}$ \\
\hline $\begin{array}{l}\text { Branco et } \\
\text { al. (2014) }\end{array}$ & $\begin{array}{l}\text { Tagus River } \\
\text { Watershed } \\
\text { (Portugal } \\
\text { and Spain) }\end{array}$ & $\begin{array}{l}29 \text { dams built between } \\
1928 \text { and } 2004 . \\
\text { Analysis over a multi- } \\
\text { year span ending in } \\
2014 \text {. }\end{array}$ & $\begin{array}{l}\text { Habitat Suitability } \\
\text { Index (HSI) } \\
\text { modeling and } \\
\text { optimized } \\
\text { removal method. }\end{array}$ & $\begin{array}{l}\text { Optimized dam } \\
\text { removal project can } \\
\text { restore habitat } \\
\text { connectivity } 35-37.2 \% \text {. }\end{array}$ \\
\hline $\begin{array}{l}\text { Cui et al. } \\
\text { (2014) }\end{array}$ & $\begin{array}{l}\text { Sandy River: } \\
\text { Former site } \\
\text { of Marmot } \\
\text { Dam, } \\
\text { Oregon }\end{array}$ & $\begin{array}{l}\text { Two parts: Sediment } \\
\text { transport models } \\
\text { before } 2007 \text { removal } \\
\text { and deposition } \\
\text { monitoring post- } \\
\text { removal. }\end{array}$ & $\begin{array}{l}\text { Sediment } \\
\text { Transport } \\
\text { Modeling } \\
\text { software, gravel } \\
\text { particle abrasion } \\
\text { coefficient. }\end{array}$ & $\begin{array}{l}\text { The model over- } \\
\text { predicted actual } \\
\text { sediment deposition } \\
\text { downstream, following } \\
\text { removal. }\end{array}$ \\
\hline $\begin{array}{r}\text { East et al. } \\
\text { (2015) }\end{array}$ & $\begin{array}{l}\text { Elwha River: } \\
\text { Former site } \\
\text { of Elwha } \\
\text { Dam, } \\
\text { Washington }\end{array}$ & $\begin{array}{l}\text { Immediate stages (two } \\
\text { years) following } 2011 \\
\text { removal of Elwha Dam. }\end{array}$ & $\begin{array}{l}\text { Site-specific } \\
\text { analysis of } \\
\text { changes in } \\
\text { riverbed elevation } \\
\text { and topography, } \\
\text { sediment grain, } \\
\text { size, and channel } \\
\text { orientation. }\end{array}$ & $\begin{array}{l}\text { Dam removal resorted } \\
\text { channel braiding index } \\
\text { by } 50 \% \text {, the river } \\
\text { successfully } \\
\text { transported sediment } \\
\text { to its mouth. }\end{array}$ \\
\hline
\end{tabular}




\begin{tabular}{|c|c|c|c|c|}
\hline $\begin{array}{r}\text { Kuby et al. } \\
\text { (2005) }\end{array}$ & $\begin{array}{l}\text { Willamette } \\
\text { River } \\
\text { Watershed, } \\
\text { Oregon }\end{array}$ & $\begin{array}{l}\text { Study focuses pm } 2005 \\
\text { statistics for } \\
\text { hydropower, fish } \\
\text { passage, flood control, } \\
\text { etc. to generate } \\
\text { metrics for modeling } \\
\text { analysis. }\end{array}$ & $\begin{array}{l}\text { Combinatorial } \\
\text { multiobjective } \\
\text { optimization } \\
\text { models for } \\
\text { analyzing da } \\
\text { removal trade- } \\
\text { offs. }\end{array}$ & $\begin{array}{l}12 \text { dam removals } \\
\text { restore } 52 \% \text { of basin } \\
\text { with only } 1.6 \% \\
\text { hydropower and } \\
\text { storage reduction. }\end{array}$ \\
\hline $\begin{array}{r}\text { Magilligan } \\
\text { et al. } \\
(2016)\end{array}$ & $\begin{array}{l}\text { Amethyst } \\
\text { Brook, } \\
\text { Massachuse } \\
\text { tts }\end{array}$ & $\begin{array}{l}\text { Several months } \\
\text { following } 2012 \text { removal } \\
\text { of river-run industrial } \\
\text { dam. }\end{array}$ & $\begin{array}{l}\text { Cross-section } \\
\text { data at multiple } \\
\text { scales to look at } \\
\text { channel-bed } \\
\text { profiles, sediment } \\
\text { size. Electro- } \\
\text { fishing surveys for } \\
\text { species richness. }\end{array}$ & $\begin{array}{l}\text { Researchers } \\
\text { documented the return } \\
\text { of four aquatic species } \\
\text { to upstream habitat of } \\
\text { former dam and } \\
\text { spawning activities as } \\
\text { well. }\end{array}$ \\
\hline $\begin{array}{r}\text { Poff and } \\
\text { Hart (2002) }\end{array}$ & $\begin{array}{l}\text { A series of } \\
\text { large-dam } \\
\text { service and } \\
\text { disservices } \\
\text { throughout } \\
\text { the US }\end{array}$ & $\begin{array}{l}\text { Focuses on major } \\
\text { infrastructure projects } \\
\text { from the 1930-70's to } \\
\text { study current (2002) } \\
\text { variations and removal } \\
\text { feasibility. }\end{array}$ & $\begin{array}{l}\text { Study utilizes } \\
\text { conceptual } \\
\text { models to } \\
\text { evaluate how } \\
\text { dams impair } \\
\text { ecosystems, } \\
\text { classification of } \\
\text { structures and } \\
\text { frameworks for } \\
\text { removal } \\
\text { decisions. }\end{array}$ & $\begin{array}{l}\text { Aging dams are } \\
\text { projected to increase } \\
\text { need for removal } \\
\text { evaluations as time } \\
\text { goes on. There is a } \\
\text { need for better } \\
\text { predictive mechanisms } \\
\text { to optimize dam } \\
\text { removal. }\end{array}$ \\
\hline $\begin{array}{r}\text { Quiñones } \\
\text { et al. } \\
\text { (2015) }\end{array}$ & $\begin{array}{l}24 \text { dams in a } \\
\text { series of } \\
\text { watersheds } \\
\text { in Central } \\
\text { and } \\
\text { Northern } \\
\text { California }\end{array}$ & $\begin{array}{l}\text { Data collection: } 2013- \\
2014 .\end{array}$ & $\begin{array}{l}\text { Scoring rubric (0- } \\
3 \text { ) for a series of } \\
\text { factors that } \\
\text { influence } \\
\text { salmonid habitat } \\
\text { suitability }\end{array}$ & $\begin{array}{l}\text { An analysis of } 12 \text { of } 24 \\
\text { dams yielded at least } \\
\text { moderate benefit } \\
\text { following removal }\end{array}$ \\
\hline $\begin{array}{l}\text { Tomsic et } \\
\text { al. (2007) }\end{array}$ & $\begin{array}{l}\text { Former site } \\
\text { of St. John } \\
\text { Dam on } \\
\text { Sandusky } \\
\text { River, Ohio }\end{array}$ & $\begin{array}{l}\text { Immediately following } \\
2007 \text { dam removal. }\end{array}$ & $\begin{array}{l}\text { HSI modeling at } \\
45 \text { cross-sections } \\
\text { and ArcGIS } \\
\text { modeling for pre- } \\
\text { and post- dam } \\
\text { removal } \\
\text { successions. }\end{array}$ & $\begin{array}{l}\text { Considerable HSI } \\
\text { increase upstream and } \\
\text { downstream of former } \\
\text { dam for fish and } \\
\text { invertebrates. }\end{array}$ \\
\hline $\begin{array}{r}\text { Zheng and } \\
\text { Hobbs } \\
(2013)\end{array}$ & $\begin{array}{l}139 \text { dams in } \\
10 \\
\text { watersheds } \\
\text { in the Lake } \\
\text { Erie basin. }\end{array}$ & $\begin{array}{l}\text { Data collection period } \\
\text { of multiple years } \\
\text { before } 2013 \\
\text { publication. }\end{array}$ & $\begin{array}{l}\text { Multi-objective } \\
\text { portfolio analysis } \\
\text { (MOPA) of dam } \\
\text { removal potential } \\
\text { based on public } \\
\text { safety, aquatic } \\
\text { species health } \\
\text { and cost. }\end{array}$ & $\begin{array}{l}\text { There are trade-offs } \\
\text { between fish health } \\
\text { and safety optimization } \\
\text { that challenge } \\
\text { management bodies. } \\
\text { MOPA is a flexible and } \\
\text { useful tool for policy } \\
\text { makers to assess } \\
\text { potential for dam } \\
\text { removal. }\end{array}$ \\
\hline
\end{tabular}


Chapter 3: Study Area

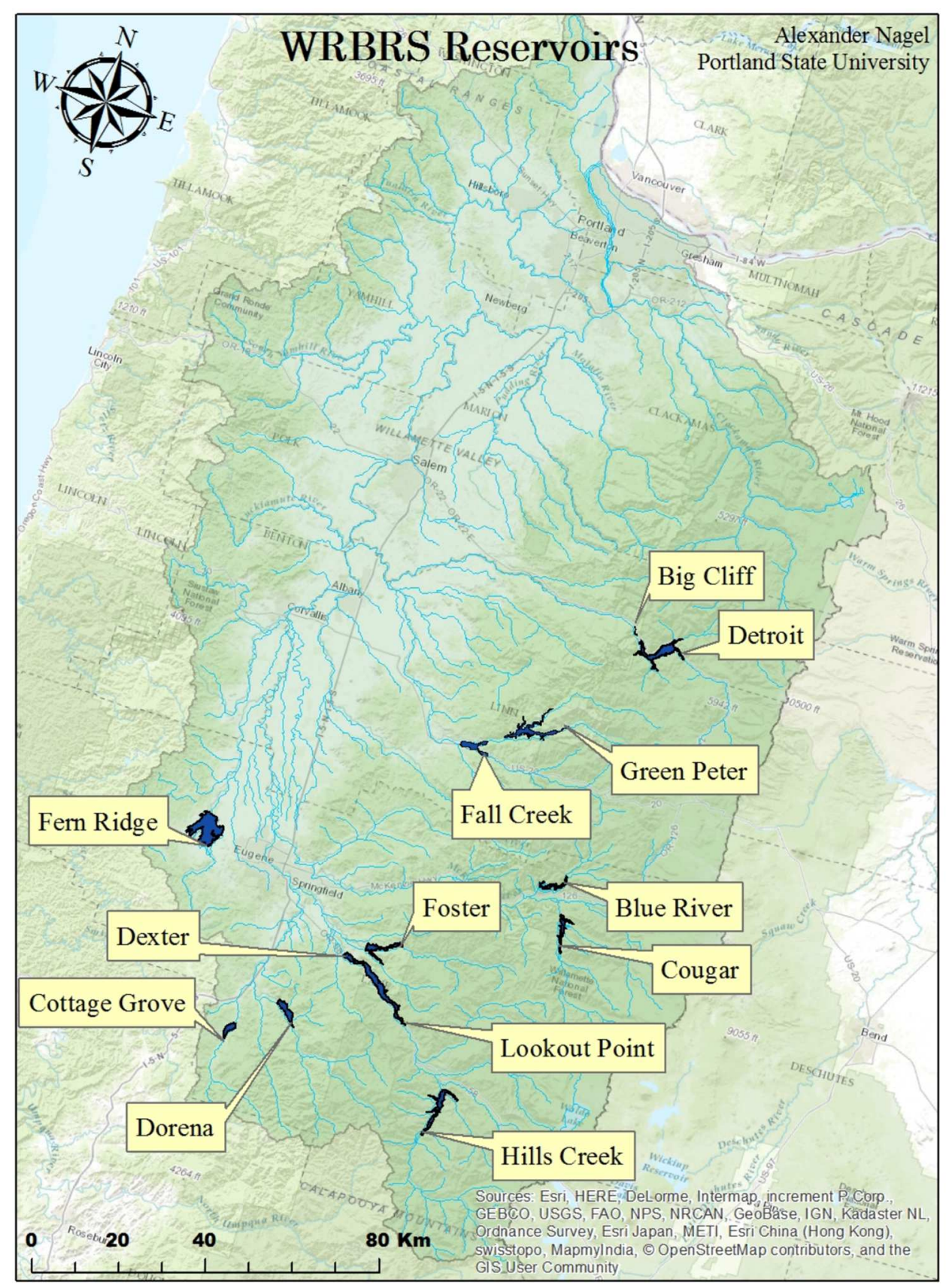

Figure 1. Map of Willamette Basin Reservoir System (WRBRS) Dams (Data Sources: ESRI, 2017. Oregon Geospatial Library, 2017. USACE, 2016, 2017.)

The Willamette River is among the most voluminous waterways in the western United States. As the second most substantial subbasin of the Columbia Watershed in 
terms of discharge, its nexus of tributaries converge along a valley floor that hosts the mainstem waterway. The presence of rich and diverse soils produce a fertile corridor that attracted agricultural opportunity during the era of western settlement (Sinclair, 2005). The temperate, maritime climate is conducive to a diversity of crops reliant on a positive Moisture Index (Thornthwaite, 1955). However, the geography of the Willamette and its tributaries are such that high seasonal runoff fluctuation would deliver winter flows that inundated agricultural land during peakflows and jeopardize harvests (Rapp, 2015).

Meanwhile, population centers throughout the Willamette Valley grew, facilitated by infrastructure projects that improved transportation and living standards in an industrializing economy (Reisner, 1986). The reclamation era, spearheaded by projects like the Hoover and Bonneville Dams quickly infiltrated the agendas of water rights holders in the Willamette Valley, who perceived the hydrology of the watershed as profitable if properly managed (Wilkinson, 1992). Lack of regulation and congressional mandate by virtue of three installments of federal Flood Control Acts in 1936, 1944, and 1960, opened the door for construction of the WRBRS (U.S. Congress, 1960). The 13 impoundments that now inhabit the Willamette network were built between 1941 and 1969, representing a dramatic transformation from a series of energetic and variable tributaries to a group of lakes tamed by management based on flood control and hydropower generation (Magilligan, 2016). Table 2 below provides a general orientation of the functions and characteristics of the structures that will subsequently be discussed in detail. 
Table 2. Characteristics of WRBRS Dams

\begin{tabular}{|c|c|c|c|c|c|}
\hline Dam Name & $\begin{array}{l}\text { Primary } \\
\text { Function * }\end{array}$ & $\begin{array}{l}\text { Full Pool } \\
\text { Reservoir } \\
\text { Capacity }\end{array}$ & Host River * & Coordinates * & $\begin{array}{l}\text { Elevation } \\
\text { (meters) * }\end{array}$ \\
\hline Big Cliff & Hydropower & $\begin{array}{l}6,450 \text { acre- } \\
\text { feet }\end{array}$ & $\begin{array}{l}\text { North Fork } \\
\text { Santiam }\end{array}$ & $\begin{array}{l}44.75^{\circ} \mathrm{N} \\
122.28^{\circ} \mathrm{W}\end{array}$ & $369 m$ \\
\hline Blue River & $\begin{array}{l}\text { Flood } \\
\text { Regulation }\end{array}$ & $\begin{array}{l}89,500 \text { acre- } \\
\text { feet }\end{array}$ & $\begin{array}{l}\text { Blue } \\
\text { (McKenzie) }\end{array}$ & $\begin{array}{l}44.17^{\circ} \mathrm{N} \\
122.33^{\circ} \mathrm{W}\end{array}$ & $415 m$ \\
\hline $\begin{array}{l}\text { Cottage } \\
\text { Grove }\end{array}$ & $\begin{array}{l}\text { Flood } \\
\text { Regulation }\end{array}$ & $\begin{array}{l}32,900 \text { acre- } \\
\text { feet }\end{array}$ & $\begin{array}{l}\text { Coast Fork } \\
\text { Willamette }\end{array}$ & $\begin{array}{l}43.72^{\circ} \mathrm{N} \\
123.05^{\circ} \mathrm{W}\end{array}$ & $246 m$ \\
\hline Cougar & Hydropower & $\begin{array}{l}219,000 \text { acre- } \\
\text { feet }\end{array}$ & $\begin{array}{l}\text { South Fork } \\
\text { McKenzie }\end{array}$ & $\begin{array}{l}44.13^{\circ} \mathrm{N} \\
122.24^{\circ} \mathrm{W}\end{array}$ & $518 m$ \\
\hline Detroit & Hydropower & $\begin{array}{l}455,100 \text { acre- } \\
\text { feet }\end{array}$ & $\begin{array}{l}\text { North Fork } \\
\text { Santiam }\end{array}$ & $\begin{array}{l}44.72^{\circ} \mathrm{N} \\
122.25^{\circ} \mathrm{W}\end{array}$ & $482 m$ \\
\hline Dexter & Hydropower & $\begin{array}{l}29,900 \text { acre- } \\
\text { feet }\end{array}$ & $\begin{array}{l}\text { Middle Fork } \\
\text { Willamette }\end{array}$ & $\begin{array}{l}43.92^{\circ} \mathrm{N} \\
122.81^{\circ} \mathrm{W}\end{array}$ & $214 m$ \\
\hline Dorena & $\begin{array}{l}\text { Flood } \\
\text { Regulation }\end{array}$ & $\begin{array}{l}77,600 \text { acre- } \\
\text { feet }\end{array}$ & Row & $\begin{array}{l}43.79^{\circ} \mathrm{N} \\
122.96^{\circ} \mathrm{W}\end{array}$ & $264 m$ \\
\hline Fall Creek & $\begin{array}{l}\text { Flood } \\
\text { Regulation }\end{array}$ & $\begin{array}{l}125,000 \text { acre- } \\
\text { feet }\end{array}$ & Fall Creek & $\begin{array}{l}43.94^{\circ} \mathrm{N} \\
122.76^{\circ} \mathrm{W}\end{array}$ & $256 \mathrm{~m}$ \\
\hline Fern Ridge & $\begin{array}{l}\text { Flood } \\
\text { Regulation }\end{array}$ & $\begin{array}{l}116,800 \text { acre- } \\
\text { feet }\end{array}$ & Long Tom & $\begin{array}{l}44.12^{\circ} \mathrm{N} \\
123.30^{\circ} \mathrm{W}\end{array}$ & $116 \mathrm{~m}$ \\
\hline Foster & Hydropower & $\begin{array}{l}60,700 \text { acre- } \\
\text { feet }\end{array}$ & $\begin{array}{l}\text { South Fork } \\
\text { Santiam }\end{array}$ & $\begin{array}{l}4.41^{\circ} \mathrm{N} \\
122.67^{\circ} \mathrm{W}\end{array}$ & $214 m$ \\
\hline $\begin{array}{l}\text { Green } \\
\text { Peter }\end{array}$ & $\begin{array}{l}\text { Flood } \\
\text { Regulation }\end{array}$ & $\begin{array}{l}249,900 \text { acre- } \\
\text { feet }\end{array}$ & $\begin{array}{l}\text { South Fork } \\
\text { Santiam }\end{array}$ & $\begin{array}{l}4.45^{\circ} \mathrm{N} \\
122.55^{\circ} \mathrm{W}\end{array}$ & $279 m$ \\
\hline Hills Creek & $\begin{array}{l}\text { Flood } \\
\text { Regulation }\end{array}$ & $\begin{array}{l}355,500 \text { acre- } \\
\text { feet }\end{array}$ & $\begin{array}{l}\text { Middle Fork } \\
\text { Willamette } \\
\text { \& Hills Creek }\end{array}$ & $\begin{array}{l}43.71^{\circ} \mathrm{N} \\
122.45^{\circ} \mathrm{W}\end{array}$ & $472 m$ \\
\hline $\begin{array}{l}\text { Lookout } \\
\text { Point }\end{array}$ & $\begin{array}{l}\text { Flood } \\
\text { Regulation }\end{array}$ & $\begin{array}{l}455,800 \text { acre- } \\
\text { feet }\end{array}$ & $\begin{array}{l}\text { Middle Fork } \\
\text { Willamette }\end{array}$ & $\begin{array}{l}43.92^{\circ} \mathrm{N} \\
122.75^{\circ} \mathrm{W}\end{array}$ & $287 \mathrm{~m}$ \\
\hline
\end{tabular}

Note: * Data from ODWR, 1998; NID, 2016; USACE, 2016, 2017.

Following completion, the WRBRS succeeded in providing the services

designated for each dam in the system. Beyond flood control and energy production, the reservoirs have developed into popular recreational areas. Agriculture benefited from reliable irrigation sources and municipalities were allocated water for public utility 
water supply (USACE, 2017). However, alongside this success were byproducts harmful to riparian habitats. Foremost is the more than $55 \%$ reduction in anadromous fish runs throughout the watershed (Wilkinson, 1992). This is not to mention the habitat fragmentation caused by dam's bifurcation of rivers that can result in higher downstream temperatures, harmful to aquatic biota. During the early 1980 's, backlash from environmental groups compelled USACE to adapt their policies for aquatic area management (ODFW, 2007). This included management delegation to the Oregon Department of Fish and Wildlife (USACE, 2015). Also, the Endangered Species Act (ESA) and Clean Water Act (CWA) compelled the USACE to implement programs such as temperature regulation, fish relocation and collaboration with local environmental organizations to safeguard against potential removal, because each dam has financial incentive for the Corps. Such efforts have curtailed the intensity of habitat impact, yet are incapable of restoring conditions to pre-dam levels. Currently, USACE is steadfast in continuing to commission each of the WRBRS structures.

Despite inspections in 2010, determining several spillway gates may not operate properly when water levels are high and considerable pressure is acting on the gates, USACE has been pursuing long-term gate rehabilitation at its Willamette Valley Project dams (Allen, 2001). The forthcoming section will delve into the issues faced by each WRBRS structure in terms of evaluating its services and disservices. Specifically, it focuses on the primary functions as defined by the NID, and the successes and failures of these criteria during their lifespans. 
Big Cliff Dam

Big Cliff Dam serves as one of two re-regulation dams in the WRBRS. Working in collaboration with Detroit Dam, its location on the North Fork Santiam River is reliant upon, and secondary to the functions of its larger upstream partner. Big Cliff generates electricity from one turbine and is a check on the flow regime from Detroit (USACE, 2016). The Flood Control Act of 1938 was the primary driver for the construction of Big Cliff, and has been a vital backup reservoir during high discharge events (Wyant, 2012).

The primary concern with Big Cliff is that its obstruction of the North Santiam has caused upwards of $75 \%$ population loss for anadromous fish, notably the Chinook salmon. USACE did not implement a fish ladder when the dam was constructed, citing geographic and financial limitations (Angilletta, 2008). Watershed councils have advocated for retrofitting, but any meaningful passage improvement is contingent upon Detroit Dam undergoing the same process, which represents a substantial investment that the USACE has been reluctant to pursue (Wyant, 2012). What has transpired on the Santiam is a hatchery program that has offset the drastic mortality rates of native fish, yet has been futile overall in compensating for the millions of fish that cannot return to upstream spawning grounds and complete their anadromous cycle (Schreck, 2012).

Big Cliff Dam is one of the older WRBRS structures. Its buttress construction style was necessary for the narrow canyon it inhabits. This dam is more seismically vulnerable than arch dams that are more easily reinforced. The relationship with Detroit creates complications for analyzing big cliff, yet insight can be gained from seeing the level to which it prevents flooding and generates hydropower against the other WRBRS dams. 
Blue River Dam

Located on a tributary of the McKenzie River, Blue River Dam is the WRBRS project. Completed in 1969, this rockfill structure has helped prevent flood damage on the mainstem McKenzie, which sees its confluence with the Willamette around the populated area of Eugene/Springfield (USACE, 2016). The dam operates in collaboration with nearby Cougar Dam and is smaller in terms of reservoir storage, does not produce hydropower and hosts a small recreational industry compared to other WRBRS reservoirs. That said, USACE prioritizes Blue River third for annual drawdown, indicating its importance for mitigating floods through a downstream channel hosting agriculture and several towns before its terminus at the mainstem Willamette (ODWR, 1998).

Although this dam is comparatively new, it has experienced issues with its spillway that had for some time been leaching toxic materials such as lead downstream. The McKenzie River and its tributaries are among the most popular angling regions in Oregon, spurring backlash from local environmental advocacy groups (Grasso, 2015). Although this issue was resolved, the spillway has been a consistent challenge for the USACE operators, who despite seismic hazards haven't invested in upgrades. This provides insight into the structural risk of the WRBRS as a whole, because several of the dams are decades older and were built with similar materials (USACE, 2016)

In analyzing Blue River, the challenge lies in balancing its important role for flood mitigation against its isolation, which prevents much recreation, as well as its structural issues. Whether its negative qualities are pronounced enough to expose Blue River as at outlying structure will be reliant on careful consideration of these criteria. 


\section{Cottage Grove Dam}

Cottage Grove Dam is one of two WRBRS structures on the Coast Fork of the Willamette River. Along with Fern Ridge, this project was part of the first installment of dams built by the USACE following the Flood Control Act of 1938 (USACE, 2011). This earthfill structure has a concrete spillway and has hosted recreational activity since its commissioning. However, as an early component of the WRBRS, its utility has been superseded by newer and larger reservoirs (ODWR, 1998). The dam continues to regulate downstream flows, which has prevented damage in downstream Cottage Grove during certain flood events. Among its primary recreational attributes is a shoreline managed to provide habitat for numerous species (USACE, 2016).

As one of the lower elevation reservoirs, Cottage Grove has developed temperature issues that often climb to hazardous levels during summer months (USGS, 2017). With the Coast Fork Willamette being a historically abundant run for anadromous fish, this obstruction, along with its neighbor, Dorena, have contributed to massive population depletions. Despite the topographic profile around Cottage Grove Dam being planar and wide, the USACE has not installed fish ladders, and instead relies on its basinwide hatchery program (Kuby, 2005). Consistent with the rest of the Willamette Watershed, these efforts have to an extent mitigated the severity of population loss, but ultimately have not been adequate in preventing declines. Summer water temperatures, often above $18.0^{\circ} \mathrm{C}$ (the EPA threshold for hazardous thermal levels) have impacted all aquatic species, including both native and hatchery fish. Therefore, Cottage Grove Dam is very reliant on its role for flood control in offsetting several ecological issues. 


\section{Cougar Dam}

Situated in a narrow canyon on the South Fork McKenzie River, Cougar Dam is a tall, rockfill structure constructed in 1963 that hosts two hydropower turbines capable of generating 25 megawatts of energy (USACE, 2016). Working in collaboration with Blue River Dam, Cougar controls flooding on the mainstem McKenzie and maintains operations making it perhaps the most uniquely managed WRBRS structure. Foremost, the lone temperature regulation tower in the WRBRS functions to provide more natural water temperatures "downstream to improve survival of Chinook eggs, juveniles and adults" (NOAA, 2017). Since the tower's construction in 2004, the annual days exceeding $18.0^{\circ} \mathrm{C}$ has dropped significantly. In 2016's water year, Cougar's downstream gaging station had 32 fewer hazardous days than neighboring Blue River (USGS, 2017).

Management at Cougar is working to implement a fish relocation program to attempt to restore spawning grounds for the influx of anadromous species navigating to the dam's spillway. USACE claims that Cougar Dam cannot accommodate a fish ladder, instead pursuing an adult collection facility designed to corral and then transport Chinook Salmon (the most abundant fish species in this area) upstream above the dam in order to provide access to their original spawning habitat (NOAA, 2017). This operation has had success, however, Chinook populations on the McKenzie and its tributaries continue to drop because of the limitations of transporting salmon, not to mention the deleterious impact this process has on some of the species (Schreck, 2012). That said, Cougar is the only WRBRS structure currently being surveyed for a fish ladder, confirming that this dam's operation is among the most progressive in the watershed. 
Detroit Dam

Perhaps the most prominent of the WRBRS dams, Detroit dam on the North Fork of the Santiam River is an expansive concrete structure that hosts one of the most popular recreation sites in the state of Oregon (Reinhardt, 2017). With full pool storage over more than 455,000 acre-feet, its size is exceeded only by Lookout Point reservoir (ODWR, 1998). Two hydropower turbines generate 100 megawatts, which has the potential to power 80,000 homes (CEA, 2010). The reservoir works in coordination with downstream Big Cliff Dam to regulate flooding on the Santiam and subsequently the mainstem Willamette through the state capital, and also plays an important role in the water levels that discharge through downtown Portland (Sinclair, 2005).

Detroit Dam is a backbone of the WRBRS. Nevertheless, its presence on a once abundant Salmon corridor has drawn criticism from environmental groups, who see the lack of ladders and an unsatisfactory hatchery system as USACE negligence (Kruzic, 2009). The North Fork Santiam has lost upwards of $75 \%$ of a once bountiful Chinook salmon run since dam installation (Evans, 2015). However, USACE cites the services provided by Detroit and the geographical parameters that preclude installation of fish passage facilities. This debate continues between dam managers and watershed councils, yet Detroit's utility in the WRBRS remains intact (USACE, 2016). The legacy of Detroit will rely on continued demand for hydropower in a changing energy grid, along with recreational popularity. The structure faces relicensing within the next decade and is overdue for seismic evaluation (NID, 2016). The magnitude of Detroit's services and pitfalls are stark, and symbolize the future of the WRBRS as a collective entity. 


\section{Dexter Dam}

Located just downstream from Lookout Point Reservoir on the Middle Fork Willamette River, Dexter Dam is one of two re-regulation structures in the WRBRS. Constructed in 1954, this dam consists of an earth and gravel fill embankment with a gated concrete spillway (USACE, 2016). Although built primarily for flood regulation along the most voluminous tributary of the mainstem Willamette, Dexter Reservoir gained public popularity quickly and hosts more than twice as many annual visitors as the much larger Lookout Point Reservoir, only three miles upstream (USACE, 2011). The lake hosts rowing clubs and is among the most popular angling sites in the region. Dexter dam also generates hydropower from a small turbine, yet its capacity is the smallest among the eight electricity producing structures in the WRBRS (ODWR, 1998).

Water quality has been a consistent issue for Dexter Dam. ODWR and U.S. Fish and Wildlife studies have recorded periodic algal blooms, low dissolved oxygen levels, and summer water temperatures that consistently break the threshold above which is considered hazardous for fish and other aquatic species (USGS, 2017). The USACE has made efforts to combat these conditions. However, climatic trends toward drier and warmer summers has posed insurmountable challenges, as lower water levels paired with high thermal penetration are out of the control of reservoir management, that needs to maintain certain flow regimes for flood prevention (USACE, 2009).

The future of Dexter Dam is linked to Lookout Point and its operations. Despite fallbacks, the reservoir is among the regions most popular for recreation, and facilitates a host of activities reliant on a consistent full pool and healthy water quality. 
Dorena Dam

As the lone WRBRS structure on the Row River, Dorena dam was constructed in 1949, during the first installment of projects following the Flood Control Act of 1938 (USACE, 2011). The Row converges with the Coast Fork Willamette before its confluence with the mainstem, and works in collaboration with Cottage Grove Dam, located less than 10 miles southwest (USACE, 2009). As an earthfill structure with a concrete spillway, Dorena does not generate hydropower and is among the least used recreational areas in the WRBRS (ODWR, 1998). However, USACE is currently working with Dorena Hydro (a private company) to build a powerhouse, originally scheduled for completion in 2016, yet remains under construction. The projected output mirrors Dexter, as one of the lower capacity facilities (USACE, 2016). Limitations are based on the size of Dorena Dam, as well as the discharge of the Row River, which is lower than the more voluminous tributaries (USGS, 2017). This project is occurring at a time when the northwest power grid is dealing with surplus electricity stemming from growing wind turbine infrastructure along the Columbia gorge (Scherer, 2016).

USGS gaging stations downstream from Dorena Dam confirm reports asserting that summer temperatures consistently rise above healthy levels for aquatic species (USGS, 2017). This is exacerbated by the fact that fish are confined to lower reaches of the Row, which has been understood since the 1970's as one of Oregon's tributaries whose lack of upper river access to anadromous fish is most impactful (Allen, 1976). USACE have been criticized for focusing on hydropower as opposed to implementing fish passage, yet the default response of financial and geographic limitations is cited. 


\section{$\underline{\text { Fall Creek Dam }}$}

The WRBRS system had been functioning for more than two decades before the construction of Fall Creek Dam. A renewed Flood Control Act in 1960 leveraged the USACE to build a new series of Dams designed to bolster flood control management and supplement the Columbia hydropower grid (USACE, 2011). With its source in the Willamette National Forest running off from the Cascades, Fall Creek converges with the Middle Fork Willamette downstream from Dexter Reservoir and functions in coordination with the operations of Lookout Point Dam. This earthfill structure does not support hydropower, yet with its close proximity to two power generating structures is managed primarily for regulating inflows to the Middle Fork Willamette (USACE, 2016).

Fall Creek is among the Willamette tributaries with lower discharge, which seems to parallel a greater susceptibility to higher summer temperatures based on lower reservoir and downstream channel levels that are more severely impacted by thermal penetration (USGS, 2017). Along with Cougar Dam, the USACE work with ODFW to perform fish relocation at Fall Creek (USACE, 2016) This program is a response to the designation of Chinook Salmon on the endangered species list, and also to promote the recovery of the Oregon Chub, whose numbers have plummeted since the introduction of dams throughout its habitat (USACE, 2011). This program has helped prevent the complete eradication of the targeted species, yet draws skepticism from biologists, who assert that ladders are a less traumatic method for reconnecting species to upstream spawning grounds (Schreck, 2012). Continued monitoring of salmonids above and below the dam is integral to understanding the success of the fish collection program. 
Fern Ridge Dam

Constructed in 1941 by the U.S. Army Corps of Engineers, Fern Ridge dam was the first step in the series of projects that comprise the WRBRS (ODWR, 1998). As one of 13 dams that currently regulates flow into the mainstem Willamette, the presence of Fern Ridge has transformed its surrounding area from a flood basin, home to the confluence of the Long Tom River and Coyote Creek, to an extensive multi-use area inhabited by a diversity of wild species and host to human activities alike. Until 1981, water quality studies of the notably shallow lake lacked consistency and transparency until an EPA-funded study by the Clean Lakes Program revealed high concentrations of noxious bacteria and algae (Johnson, 2015). Despite the USACE response of community outreach and the introduction of ODFW as an administrative body, the reservoir has consistently failed to meet standards for water quality, temperature, turbidity and dissolved oxygen, resulting in the demise of multiple aquatic species (Thieman, 2007).

Meanwhile, Fern Ridge reservoir is among the most popular areas for recreation in the Willamette Valley. The area attracts over 1 million annual visitors, to parks and picnic areas, a boat marina, and trails for hiking and bird watching (USACE, 2016). The reservoir earns substantial revenue for the local area, despite the dam not generating hydropower. Certainly, the age of Fern Ridge dam (76 years), as well as its lowest drawdown priority status among the WRBRS dams marks it as an outlier in some major criteria. The focus in analyzing Fern Ridge will be to assess whether its lucrative recreational qualities can outweigh the numerous biophysical hazards created by the presence of this dam that experiences severe seasonal fluctuation. 
Foster Dam

Although not considered a re-regulation structure, Foster Dam is located directly downstream from the larger Green Peter facility at the confluence of the South and Middle Forks of the Santiam River (USACE, 2016). Built in tandem in 1968, these dams were part of the final effort taken by the USACE to respond to U.S. Flood Control Act of 1960, which was articulated in congresses Columbia Basin plan specifically authorizing the construction of Foster Reservoir "in accordance with the recommendations of the Chief of Engineers" (U.S. Congress, 1960). Since Green Peter focuses its releases on optimizing power generation, Foster Dam's primary purpose is normalization of runoff from the South Fork into the mainstem Willamette (USACE, 2017). This structure also generates 20 megawatts of electricity, capable of powering 20,000 homes (CEA, 2010).

Foster Reservoir hosts a diversity of aquatic and terrestrial species that are protected in coordination with the ODFW as part of the Foster Lake Project (USACE, 2016). Species include the cutthroat trout, western pond turtle, and Chinook salmon. Similar to Fall Creek and Cougar Dams, Foster has responded to an obstructed channel passage with a fish relocation program and hatchery system. Historically, the Santiam network was perhaps the most abundant salmon migration throughout the Willamette's tributaries. Plummeting Chinook populations have been slowed by USACE efforts, yet annual spawning in the upper reaches of the river continue to drop.

Foster Dam is one of the most popular recreation sites in the WRBRS, and has been at the forefront of projects carried out by USACE to offset ecological impacts. A continued focus on habitat restoration will be imperative to its legacy (USACE, 2016). 


\section{Green Peter Dam}

Green Peter Dam creates one of the largest reservoirs in the WRBRS. As a concrete gravity dam, it inhabits a steep gorge that harnesses forceful discharge from the Middle Fork Santiam (USGS, 2017). Its collaboration with Foster Dam is estimated by USACE to have prevented $\$ 1.5$ billion in damages since its 1968 commissioning (USACE, 2016). However, this figure, along with all of the flood control data professed by USACE have come into question in recent years. While these metrics are considered generally accurate based on current conditions, geomorphological studies evaluating channel dynamics on the Santiam network have concluded that the presence of dams has altered the river in such a way that their straightening and hardening "tends to increase the energy of the river during floods and potentially creates accelerated erosion at other locations" (Avery, 2014). Nonetheless, large storage capacity of Green Peter Reservoir supports recreation and abundant energy production despite high runoff fluctuation.

Green Peter has the longest shoreline in WRBRS, thus the USACE has put considerable resources into habitat restoration and increasing access one of the more remote reservoirs in the system (USACE, 2016). Acknowledging these factors, operation of this area requires a delicate balance, easily be upset by changing climatic conditions. Originally focused primarily on energy optimization and flood control in coordination with Foster, Green Peter would drain considerably, and the river between dams would get low during summer month (Kruzic, 2008). Pressures from NOAA mandate draining and filling strategies be complaint with the ESA for aquatic species protection (Linn, 2011). Such conditions require USACE to apply dynamic management to this dam. 
$\underline{\text { Hills Creek Dam }}$

Hills Creek Dam is situated at the confluence of the Middle Fork Willamette River and Hills Creek, upstream from Lookout Reservoir. This structure begins the process of managing flow of the most voluminous feeder into the mainstem Willamette (USGS, 2017). Constructed in 1953, Hills Creek was a component of the second wave of impoundment projects that changed the complexion of the Willamette Basin from an intermittently altered network to a comprehensively managed watershed (Sinclair, 2005). Hills Creek Dam generates hydropower sufficient to power 30,000 residences and is cited by the USACE as the most vital constituent of the basin-wide flood management plan besides Detroit, Green Peter, and Lookout Point Reservoirs, the three of which alone store more than $50 \%$ of the Willamette's drainage (Kuby, 2005). Therefore, the paramount function of Hills Creek Dam is to provide an adaptable and consistent release regime that minimizes stress on downstream structures (USACE, 2016).

To confront anadromous fish depletion in the Middle Fork subbasin, USACE relies on the Willamette Fish Hatchery near Oakridge. The facility is operated by ODFW, with funds provided by the USACE and the State of Oregon (USACE, 2009). However, financial constraints for the overseeing agencies has opened bidding for privatization for six Oregon hatcheries, Willamette included. Such a transfer would transform a system in which hatchery management is beholden to federal standards and creates uncertainty on whether "there will be the same level of fish production and quality" (AP, 2017). Already, the Middle Fork Willamette has experienced consistent anadromous species declines under USACE commissioned hatchery and relocation programs. 


\section{$\underline{\text { Lookout Point Dam }}$}

Constructed in 1953, Lookout Point Dam plugs the Middle Fork Willamette River to fill the largest capacity reservoir in the WRBRS (NID, 2016). Three hydropower turbine units capable of generating 120 megawatts of electricity designate Lookout Point as the most productive structure in the WRBRS (CEA, 2016). This reservoir has the highest drawdown priority alongside an estimate of more than $\$ 5$ billion prevented in flood damages (ODWR, 1998). These superlatives support the USACE management decision to allocate this reservoir the highest operating budget among the WRBRS structures (USACE, 2017). This financial latitude has supported USACE led projects focused on adapting to changing a $21^{\text {st }}$ century socioeconomic landscape that values dam costs and benefits differently than during the reclamation era when the WRBRS was assembled.

Notable projects at Lookout Point include proposed fish passage retrofitting, scheduled for completion in 2021. Contingent upon Dexter Dam also constructing a fish ladder, a successful installation would be the first opportunity for anadromous fish to return to spawning grounds on their own accord (NOAA, 2017). This responds to a 2008 basin-wide study outlining policies for future compliance with the ESA (USACE, 2011). Another major upgrade to Lookout Point was a 2016 spillway rehabilitation that included upstream Hills Creek Dam (USACE, 2016). 2010 Federal Energy Regulatory Commission (FERC) inspections revealed susceptibility to seismic events, not to mention high discharge years that stress spillway gates to the verge of collapse. The successes and failures of these projects at Lookout Point are an important indicator of WRBRS capability to continue to function reliably and adapt to changing conditions. 


\section{Chapter 4: Data and Methods}

To comprehensively analyze the WRBRS, this study is informed by an evaluation of the characteristics of each structure, alongside literature review of research in hydroscience, which supports the criteria representing services and disservices. Services are derived directly from USACE, who are administratively required to claim each reservoir's utilities prior to commission (USFS, 2009). Included are flood control, hydropower, irrigation, recreation, and water quality (USACE, 2016). However, as a quantitative study, selected criteria rely on services for which data can be discerned between structures. Additionally, the NID provides official primary service functions for U.S. dams, and within the WRBRS the functions cited are hydropower generation and flood control (NID, 2016). The justification for including recreation as a service is because this is the only other primary function designated for major federally-owned dams and is touted by USACE and affiliated organizations as a fundamental operation of the reservoirs that drives management practices (Willamette, 2015). The amalgam of these criteria does not encompass all dam benefits. However, for this particular watershed they comprise the backbone of dam utilities. Further analysis may include criteria such as irrigation and public utility water distribution for services, $\mathrm{CO}_{2}$ generation or sediment imbalance for disservices. For the latter two especially, analysis require sophisticated hydrologic modeling beyond the scope of this project, which seeks to evaluate the integral components of WRBRS dams, yet acknowledges time and resource limitations.

The services are balanced by dam impacts, chosen based on a similar rationale. While the list of known disservices created by dams has expanded since removal 
projects have provided a template for assessing habitat response to channel restoration, the most pressing issues in the Willamette Watershed concern fish and habitat conditions (Kuby, 2005). Lack of fish ladders has manifested in severe species depletion and unnatural temperatures are directly related to fish mortality as well as a host of other riparian habitat issues. Therefore, this study includes both the criterion of fish species mortality and hazardous temperature conditions, because while they are somewhat interrelated, their ramifications have unique qualities that are useful in assessing the impact of channel obstruction (Zheng, 2013). While other ecological impacts are present in dam-influenced rivers, such as sediment imbalance, upstream flooding, $\mathrm{CO}_{2}$ generation, etc. the paradigm for limiting the study to two disservice variables is that it will respond specifically to the most pronounced consequences of WRBRS dams (East, 2015). Additional research can include factors that enhance the robustness of the study, yet the evaluation approach taken in this project can be used as a template for dam-related research in other watersheds, or that include more criteria.

While the focal point of this project is to perform a multi-objective analysis of dam services and disservices, using an equally weighted scoring system, a major caveat to dam utility is structural risk. Since WRBRS structures range in age from 49 to 76 years old, their feasibility certainly relies on the variables that comprise the evaluation criteria, yet are superseded by architectural risk which underlies the overall functionality of a structure (AP, 2013). An apropos example is Oroville Dam, which as the tallest dam in the nation harnesses one of California's largest reservoirs, supports hydropower generation and hosts substantial recreational activities (Megerian, 2017). These services 
were rendered as useless during a spillway emergency in early 2017 that exposed vulnerability to high runoff years and institutional inertia to confront the structural deterioration that accompanies aging dams (Nuccitelli, 2017). Oroville is one example of dozens of structural issues that manifest as dams contend against constant pressures from water, sediment and other erosive elements. Therefore, this study will include structural risk as a control variable to gain insight into the relationship between dam services, disservices and the extent to which they are influenced by structural integrity.

Since WRBRS dams are approaching ages often considered hazardous, consideration of their structural risk as a final check on benefits and ecological issues supports a multifaceted evaluation of the Willamette Watershed's impoundments. Detrimental impacts will initially be compared the positive functions (NID, 2016).

The following section will discuss the methods for scoring the criteria in-depth, and includes a decision-based support system chart (Table 3), which can be used as a template for dam managers, hydro-scientists, biologists, or other academics to organize a system for evaluating dam feasibility based on a series of variables focused on a single structure, or a series of structures. Table 3 describes the framework for this type of study, which is flexible to other variables, inducing or excluding a control, and applicable across watersheds, contingent on the idea that dams can be evaluated using relevant and discernible data that can be applied consistently to each component of the study, which in this case is the 13 WRBRS structures. 


\subsection{Overview of Methods}

The function of a scoring rubric in hydrologic analysis is that it provides both adaptability and consistency, because it is flexible in criteria selection, yet evaluates each variable on the same scale, valuable in comparative studies (Quiñones, 2015). This WRBRS study selects three services and two disservices and allocates a score of 0 to 3 and 0 to -4.5 respectively. Ideally, the same number of positive and negative criteria will be analyzed. However, this particular case study includes a control variable, otherwise a disservice, because the role of structural risk on dam feasibility eclipses other criteria since dam function is rendered as obsolete if structural integrity fails (OEMD, 2016). The initial output for each dam is an amalgam of scores that are calibrated based on the \% of the highest scoring dam (i.e. If the highest hydropower generating dam has a 100-mw output, this structure receives a 3 and a structure with $50 \%$, or $50 \mathrm{mw}$ receives a 1.5).

For results validation, the study correspondingly employs a ranking system, based on variable score rank (\#1-13) and calculates the average across five criteria. This functions as a check on the credibly of the results. Table 3 below outlines this model.

Table 3. Decision-Based Support System Outline for Dam Managers

\begin{tabular}{|l|l|l|l|}
\hline $\begin{array}{l}\text { Progression of } \\
\text { Analysis: }\end{array}$ & Step \#1 & Step \#2 & Step \#3 \\
\hline $\begin{array}{l}\text { Criteria } \\
\text { Selection }\end{array}$ & $\begin{array}{l}\text { Data collection for } \\
\text { variables (services } \\
\text { and disservices). }\end{array}$ & $\begin{array}{l}\text { Control variable } \\
\text { determination (final } \\
\text { check on relationship } \\
\text { between rubric score } \\
\text { and critical factor/s). }\end{array}$ & $\begin{array}{l}\text { Expansion or reduction of } \\
\text { criteria based on results } \\
\text { analysis and further } \\
\text { research priorities. }\end{array}$ \\
\hline $\begin{array}{l}\text { Evaluation } \\
\text { Method }\end{array}$ & $\begin{array}{l}\text { Equal output } \\
\text { scoring rubric (i.e. } \\
0- \pm 3 \text { ) or ranking } \\
\text { based (i.e. \#1-13). }\end{array}$ & $\begin{array}{l}\text { Comparison of } \\
\text { feasibility score and } \\
\text { control to analyze } \\
\text { importance of } \\
\text { variables in analysis. }\end{array}$ & $\begin{array}{l}\text { Corroboration with dam } \\
\text { managers (USACE) to } \\
\text { compare results with } \\
\text { current operation schemes. }\end{array}$ \\
\hline
\end{tabular}




\subsection{Data and Methods (Services)}

\section{Criteria \#1: Flood Regulation}

The precedent for the WRBRS was the Flood Control Act of 1938, enacted in order to reduce damage on infrastructure during peakflow events, support reliable water supply and encourage development along the fertile corridors of the nation's waterways (U.S. Congress, 1960). With high seasonal discharge fluctuation, USACE was instructed by USBR to achieve "satisfactory" control of the Willamette network to minimize potential for catastrophic events for Oregon's economic and population hubs along the valley floor (Sinclair, 2005). This latitude gave USACE the authority to build on each of the major tributaries of the mainstem Willamette over a span of two decades (ODWR, 1998). The intricate web of flow regulation structures has succeeded in preventing major channel breaches by regulating releases as well as dramatically modifying the river bank and channel bed topography of the waterways (East, 2015).

A caveat to USACE success on flood reduction is geomorphologic analysis of the diminished ability of dam influenced channels to adjust their bed and sediment storage (Cui, 2014). This is coupled with side channel elimination, which concentrates discharges and diminishes the complexity of aquatic habitats (Avery, 2014). While floods have been suppressed, anomalous events, exceeding storage capacities can result in even more severe destruction downstream. In analyzing flood mitigation, USACE provides data approximating cumulative savings secured by each dam's presence. This is bolstered by drawdown priority, determined by an amalgam of factors, including reservoir capacity, discharge, and historic records highlighting areas of vulnerability (ODWR, 1998). 


\section{Criteria \#2: Hydropower Generation}

Hydropower generation entered the $21^{\text {st }}$ century producing approximately $98 \%$ of renewable energy in the U.S. (FWEE, 2017). The 250 hydroelectric projects in the Northwest comprise $40 \%$ of the national hydro grid (Scherer, 2016). The geography of the region lends itself to this capability, since large rivers with headwaters often above 10,000 feet quickly drop to sea level, creating steep gradients that energize large turbines (Wilkinson, 1992). However, a new wave of alternatives has transformed the market and flooded the grid with affordable wind and solar power. In fact, Bonneville Power Administration (BPA), has shut down select grids of both wind and hydropower production in 2017 due to surplus electricity that results in blackouts if over-infiltrated (Flatt, 2017). An emerging divide between hydroelectric capability and necessity calls into question the future need for currently ubiquitous power generating dams.

The WRBRS has eight hydroelectric structures capable of producing electricity to power 300,000 homes. By comparison, the combined 408 megawatt capacity pales in contrast to Bonneville Dam, which alone generates more than 1,200 megawatts (USACE, 2017). However, energy distribution functions more efficiently when electricity is transported shorter distances, and USACE remains steadfast in their prioritization of maximum production for certain structures and flood control for others (Kruzic, 2008). Since three WRBRS structures generate $70-75 \%$ of the network's wattage, the utility of the lower output dams depends on the energy progression in the Northwest (USACE, 2017). This can result either in greater reliance of system-wide contributions during low runoff years, or instead a grid in which smaller dam's production is superfluous. 


\section{Criteria \#3: Recreation}

Although not based on necessity, the services provided by impounding rivers to create reservoirs have been among the most successful legacies of USACE in the Willamette Watershed. Annual visitation days throughout the WRBRS reservoirs range from 3-4 million (USACE, 2016). Activities include boating, angling, camping, and hiking. The most visited reservoir, Fern Ridge, hosts a boat marina and restaurants along its shoreline (Connolly, 2013). Hatchery programs that employ hundreds and stock fish throughout the reservoirs receive federal and state funding and generate revenue from permits, guiding services and affiliated industries (AP, 2017). However, as USACE focused their resources on flood control and hydropower generation during the early stages of the WRBRS, the ecological health of the reservoirs suffered (Sinclair, 2005).

In terms of cultural value, recreational use is the most effective evaluation method because it suggests approval for the presence of the WRBRS. While it is possible to estimate the financial value of the reservoirs, each location hosts a web of organizations that either generate revenue from reservoir operations or are allocated funds for management (Linn, 2011). Therefore, the data used for recreation analysis focuses on number of visitors in order to calibrate the importance of each dam for its surrounding community (Connolly, 1992). USACE maintains databases that estimate visitation days based on facilities usages, surveys and vehicle counts. The metrics generated for recreational usage informs the general allocation of funds for each of the WRBRS structures and the specific amount of funding dedicated to particular activities facilitated by the reservoirs and their surrounding areas (USACE, 2016). 


\subsection{Data and Methods (Disservices)}

\section{Criteria \#4: Fish Mortality}

Perhaps the most conspicuous byproduct of dams is habitat loss for anadromous fish. Nowhere has this been more severe than in the Northwest, where abundant fish runs were confronted with one of the most extensive dam construction projects in the U.S. (Reisner, 1986). This manifested in mortality levels that required the designation of Chinook salmon as an endangered species (USACE, 2011). Biologists estimate that "even passable dams with fish ladders account for a loss of about $5-13 \%$ of each run at each dam" (Wilkinson, 1992). No WRBRS structure hosts a fish ladder, which in the most severe cases has caused 75-85\% population declines (Angilletta, 2016).

Despite multiple structures along many of the Willamette's tributaries, basinscale studies conclude that even singular removals have rehabilitative effects, because habitat normalization and fewer barriers allows for more successful return to spawning grounds (Branco, 2014). The historic salmon runs on each WRBRS channel varies, but each host anadromous runs, all of which have been impacted. Increasing awareness of the severity of declines has spurred backlash against USACE, who have responded with hatchery programs, fish relocation, and surveying for fish passage retrofitting (USACE, 2013). Release schedules have been modified to maintain minimum flows suitable for fish habitats (USACE, 2016). That said, populations have not recovered to levels satisfactory for environmental groups, who maintain that USACE continues to prioritize revenue over restoration. Barring removal, USACE maintains a delicate balance between dam operation and response to ecological impacts of WRBRS structures (Tomsic, 2007). 


\section{Criteria \#5: Water Temperature Hazards}

When a dam is introduced to a river, the channel is bisected and a formerly cohesive habitat begins to develop unique characteristics. This fragmentation manifests in different ways, including "destruction of fisheries, and the overall loss of the ecosystem services on which the human economy depends" (Postel, 1997).

Concurrently, the change in magnitude and timing of flows to optimize hydropower or flood control alters the amount of time a reservoir is at full pool (Kruzic, 2008). Drawdowns that are more drastic, leaving summer fill low, experience solar penetration that heats surface water and causes higher temperatures upon release. Shallow reservoirs are more susceptible to heating. USACE has dealt with these issues through a variety of management schemes, including maintaining flow levels of comply with EPA standards for fish health (EPA, 2016) Also included is the installation of a temperature regulation tower at Cougar Dam, which successfully replicates temperatures downstream, but is the only WRBRS structure with the technology (USACE, 2005).

The consequences of unnatural heating are numerous, but most directly affect the health of aquatic species. The EPA determines an $18.0^{\circ} \mathrm{C}$ seven day moving average as the threshold above which is hazardous for fish species in lower to middle river subbasins (EPA, 2017). This metric is used to determine annual number of days above safe levels for gaging stations below each dam during the 2016 water year. The figures within the USGS water year summary are based on daily mean temperatures, which give a comprehensive assessment of the conditions directly below, and therefore influenced by the operations of the dams and their flow management schemes (USGS, 2017). 
Control Variable: Structural Risk

Similar to any infrastructure, dams age, their lifespans finite. In 2017, California's Oroville Dam, the nation's highest structure experienced failure due to deteriorating spillways, forcing the evacuation of 200,000 people downstream. (Megerian, 2017). Scientific consensus is that Oroville is not an anomaly, but was improperly managed and neglected of necessary upgrades. A rift between dam operators and structural surveyors is common, as the cost to fix a hazardous structure is exorbitant (Nuccitelli, 2017).

Fifteen-year seismic studies on Oregon dams have recently exposed high risk levels for every single dam in the Willamette Basin in the event of an earthquake along the Cascadia Subduction Zone (AP, 2013). This has compelled USACE to invest in more thorough seismic and safety inspections. However, resulting from the studies is the realization that WRBRS dams are vulnerable even without a major seismic event (NID, 2016). Evaluations in 2010 determined that many USACE "dams' spillway gates might not operate properly when water levels are high and significant pressure is acting on the gates" (USACE, 2011). Repairs of critical components at several dams demonstrate that USACE is focused on long-term gate rehabilitation. However, the average age for the WRBRS structures is 60 years, which indicates that conditions will increasingly decline, representing increasing expenditures for USACE (ODWR, 1998). The ability to confront structural decay will rely on federal congressional support, whose disposition towards dam infrastructure has been tenuous (Wilkinson, 1992). That said, tools are available for analyzing dam risk. FERC and USACE collaborate to sponsor the NID, which provides information about the structural status of each of the nation's large dams (NID, 2016). 
Table 4. Data Source Information for Services and Disservices

\begin{tabular}{|c|c|c|c|}
\hline Criteria Name & Data Sources & Description & Time Period \\
\hline $\begin{array}{l}\text { Flood Regulation } \\
\text { (Service) }\end{array}$ & $\begin{array}{l}\text { Atlas, 2017. ODWR, } \\
\text { 1998. Sinclair, 2015, } \\
\text { USACE, 2009, 2015, } \\
\text { 2016. USGS, 2017. }\end{array}$ & $\begin{array}{l}\text { Determined by calculating } \\
\text { the average rubric values } \\
\text { of drawdown priority and } \\
\text { \$ saved in flood damages. } \\
\text { Drawdown is calculated by } \\
\text { USACE and ODWR for } \\
\text { importance of flood } \\
\text { regulation on release } \\
\text { regimes. \$ saved is } \\
\text { calculated by USACE for } \\
\text { each dam's lifespan. }\end{array}$ & $\begin{array}{l}\text { 1941-2016. } \\
\text { Calculated } \\
\text { individually } \\
\text { for each } \\
\text { structure } \\
\text { since the } \\
\text { year of } \\
\text { completed } \\
\text { construction. }\end{array}$ \\
\hline $\begin{array}{l}\text { Hydropower } \\
\text { Generation (Service) }\end{array}$ & $\begin{array}{l}\text { ODWR, 2017. Scherer, } \\
\text { 2016. USACE, } 2016 . \\
\text { USACE, } 2017 .\end{array}$ & $\begin{array}{l}\text { USACE provides electricity } \\
\text { output for all Portland } \\
\text { District Hydropower } \\
\text { structures. }\end{array}$ & $\begin{array}{l}2016 \text { water } \\
\text { year. (Oct } 1^{\text {st }} \\
2015-\text { Sep } \\
31^{\text {st } 2016)} .\end{array}$ \\
\hline Recreation (Service) & $\begin{array}{l}\text { Connolly, } 2013 . \\
\text { Johnson, 2015. Linn, } \\
\text { 2011. Reinhardt, 2017. } \\
\text { OPRD, 2017. USFS, } \\
\text { 2009, USACE, 2005, } \\
\text { 2009, 2015, } 2016 .\end{array}$ & $\begin{array}{l}\text { The \# of visitor days are } \\
\text { collected by management } \\
\text { bodies who oversee } \\
\text { reservoir facilities. USACE } \\
\text { delegates roles to Parks } \\
\text { and Recreation, Fish and } \\
\text { Wildlife, etc. at some } \\
\text { projects, and maintain } \\
\text { databases for others. }\end{array}$ & $\begin{array}{l}\text { January } 1^{\text {st }} \\
2016- \\
\text { December } \\
31^{\text {st }} 2016 .\end{array}$ \\
\hline $\begin{array}{l}\text { Fish Mortality } \\
\text { (Disservice) }\end{array}$ & $\begin{array}{l}\text { Connolly, 2013. ODFW, } \\
\text { 2007, Sharpe, } 2013 . \\
\text { Tetra Tech, 2013, } \\
\text { USACE, 2011, 2013, } \\
\text { 2015. USFS, 2009. }\end{array}$ & $\begin{array}{l}\text { Environmental Impact } \\
\text { Assessments completed } \\
\text { for Willamette subbasins } \\
\text { generate values for fish } \\
\text { mortality \% below dams. }\end{array}$ & $\begin{array}{l}1941-2016 . \\
\text { Based on } \\
\text { annual } \\
\text { records. }\end{array}$ \\
\hline $\begin{array}{l}\text { Water Temperature } \\
\text { Hazards (Disservice) }\end{array}$ & $\begin{array}{l}\text { USGS, 2017, USGS } \\
2017 .\end{array}$ & $\begin{array}{l}\text { USGS gaging stations } \\
\text { downstream from each } \\
\text { dam provide daily mean } \\
\text { temperatures that are } \\
\text { used to calculate 7-day } \\
\text { moving averages. }\end{array}$ & $\begin{array}{l}2016 \text { water } \\
\text { year. (Oct } 1^{\text {st }} \\
2015-\text { Sep } \\
31^{\text {st } 2016)} .\end{array}$ \\
\hline $\begin{array}{l}\text { Structural Risk } \\
\text { (Control Variable) }\end{array}$ & $\begin{array}{l}\text { ODWR, 1998. NID, } \\
2016 .\end{array}$ & $\begin{array}{l}\text { USACE and FERC manage } \\
\text { the NID, which combines } \\
\text { factors to determine } \\
\text { structural risk level. This is } \\
\text { used to adjust rubric score, } \\
\text { based on dam age. }\end{array}$ & $\begin{array}{l}2016 \\
\text { database for } \\
\text { annual } \\
\text { calculations. }\end{array}$ \\
\hline
\end{tabular}


Chapter 5: Results

\subsection{Flood Regulation}

Table 5. Data for Criteria \#1: Flood Regulation (Service)

\begin{tabular}{|l|l|l|l|l|l|l|}
\hline Dam Name & $\begin{array}{l}\text { Drawdown } \\
\text { Priority }\end{array}$ & $\begin{array}{l}\text { Rubric } \\
\text { Score }\end{array}$ & $\begin{array}{l}\text { \$ Saved in } \\
\text { Damages * }\end{array}$ & $\begin{array}{l}\text { Rubric } \\
\text { Score }\end{array}$ & $\begin{array}{l}\text { Rank } \\
\text { (High- } \\
\text { Low) }\end{array}$ & $\begin{array}{l}\text { Average } \\
\text { Rubric Score } \\
\text { (0 to 3) }\end{array}$ \\
\hline Big Cliff & N/A & 0 & $\$ 0$ & 0 & $\# T-12$ & 0.00 \\
\hline Blue River & $3^{\text {rd }}$ Priority & 2.25 & $\$ 375$ million & 0.21 & $\# 6$ & 1.23 \\
\hline Cottage Grove & $5^{\text {th }}$ Priority & 1.5 & $\$ 1.2$ billion & 0.68 & $\# 7$ & 1.09 \\
\hline Cougar & $2^{\text {nd }}$ Priority & 2.63 & $\$ 452$ million & 0.26 & $\# 5$ & 1.45 \\
\hline Detroit & $6^{\text {th }}$ Priority & 1.13 & $\$ 3.7$ billion & 2.1 & $\# 4$ & 1.62 \\
\hline Dexter & N/A & 0 & $\$ 0$ & 0 & $\# T-12$ & 0.00 \\
\hline Dorena & $5^{\text {th }}$ Priority & 1.5 & 3.4 billion & 1.92 & $\# 3$ & 1.71 \\
\hline Fall Creek & $5^{\text {th }}$ Priority & 1.5 & $\$ 900$ million & .51 & $\# 8$ & 1.01 \\
\hline Fern Ridge & $8^{\text {th }}$ Priority & 0.38 & $\$ 415$ million & 0.23 & $\# 11$ & 0.31 \\
\hline Foster & $7^{\text {th }}$ Priority & 0.75 & $\$ 0$ & 0 & $\# 10$ & 0.38 \\
\hline Green Peter & $5^{\text {th }}$ Priority & 1.5 & $\$ 600$ million & 0.34 & $\# 9$ & 0.92 \\
\hline Hills Creek & $4^{\text {th }}$ Priority & 1.88 & $\$ 3.2$ billion & 1.81 & $\# 2$ & 1.85 \\
\hline Lookout Point & $1^{\text {st }}$ Priority & 3 & $\$ 5.3$ billion & 3 & $\# 1$ & 3.00 \\
\hline
\end{tabular}

Notes: * Data from Atlas, 2017; ODWR, 1998; Sinclair, 2015; USACE, 2016; USGS, 2017.

Drawdown Priority scores based on eight categories (1 - 8) defined by USACE (ODWR, 1998). Scores were calculated as: (9 - Priority) , 8 × 3. For example, a 2 nd priority dam receives a score of $(9-2), 8 \times 3=2.63$. Dams without drawdown information score as 0 .

USACE works in collaboration with ODWR to set reservoir fill and drain schedules that minimize flood potential (USACE, 2016). In general, larger reservoirs are higher priority, but some outliers such as Fern Ridge and Detroit have been delegated due to lower risk potential (ODWR, 1998). The corresponding figure of estimated value of $\$$ 
saved in flood damages has some correlation with drawdown priority, but is incongruous for structures such as Cougar and Blue River, whose location on the McKenzie is remote and less susceptible to infrastructure damages (USACE, 2013). The cumulative value of $\$ 19.5$ billion saved in damages is calculated by USACE for worst case scenario annual mitigation (USACE, 2016). Since 1969, the average annual savings over this 48 years is approximately $\$ 406$ million. This figure represents what would otherwise pose substantial financial liability for downstream communities (Sinclair, 2005).

The WRBRS dams have a vital role in preventing flooding in the Willamette River Watershed. However, the accumulation of water in a reservoir vastly increases the level of catastrophe in a major flood event. For example, estimates are that a failure of Hills Creek Dam could jeopardize the safety of 250,000 people and cause $\$ 10$ billion in damages (OEMD, 2016). Therefore, it is imperative that USACE maintain the WRBRS dams properly so that catastrophic potential is reduced. Investments in revamping spillways contribute to future success in preventing channel breaches. However, these are deemed by seismologists as Band-Aids that will ultimately require more substantial improvements as the older structures approach their centurion (Allen, 2001).

The rationale for combining drawdown priority with flood damage savings to generate the rubric score for this criterion is that this method encompasses current management practices and historic records. The current landscape of the Willamette Valley is distinct from 1938, when the Flood Control Act set the stage for the WRBRS (U.S. Congress, 1960). Current flood management analysis elucidates whether service levels have increased, decreased, or maintained their contribution to the WRBRS. 


\subsection{Hydropower Generation}

Table 6. Data for Criteria \#2: Hydropower Generation (Service)

\begin{tabular}{|l|l|l|l|}
\hline Dam Name & $\begin{array}{l}\text { Hydropower } \\
\text { Generation }(\mathrm{mw})^{*}\end{array}$ & $\begin{array}{l}\text { Rank \#1-13 (High- } \\
\text { Low Service) }\end{array}$ & $\begin{array}{l}\text { Rubric Score } \\
\text { (0 to 3) }\end{array}$ \\
\hline Big Cliff & 18 megawatts & $\# 7$ & 0.45 \\
\hline Blue River & No Hydropower & \# T-9 & 0.00 \\
\hline Cottage Grove & No Hydropower & \# T-9 & 0.00 \\
\hline Cougar & 25 megawatts & $\# 5$ & 0.63 \\
\hline Detroit & 100 megawatts & $\# 2$ & 2.49 \\
\hline Dexter & 15 megawatts & $\# 8$ & 0.38 \\
\hline Dorena & No Hydropower & \# T-9 & 0.00 \\
\hline Fall Creek & No Hydropower & $\#$ T-9 & 0.00 \\
\hline Fern Ridge & No Hydropower & $\#$ T-9 & 0.00 \\
\hline Foster & 20 megawatts & $\# 6$ & 0.50 \\
\hline Green Peter & 80 megawatts & $\# 3$ & 2.00 \\
\hline Hills Creek & 30 megawatts & $\# 4$ & 0.75 \\
\hline Lookout Point & 120 megawatts & $\# 1$ & 3.00 \\
\hline
\end{tabular}

Note: * Data from ODWR, 2017; Scherer, 2016; USACE, 2016; USACE, 2017.

The results illustrate substantial contrast in power generation among the WRBRS structures, which appear to fit into three categories. Five dams do not host generators and therefore do not contribute to the electric grid. Another five structures do produce power, but are low capacity turbines only capable of powering a small town (CEA, 2015). The higher production facilities are also host the greatest capacity reservoirs. Detroit, Green Peter, and Lookout Point cumulatively generate upwards of $75 \%$ of the WRBRS megawatt output. The rubric scores positively reflect the polarized nature of the watershed's hydroelectric constituents. That said, five structures are designated by FERC as primarily functioning for hydropower. This does not include Green Peter and Lookout Point, which conveys the emphasis that USCACE continues to place on this service. 


\subsection{Recreation}

Table 7. Data for Criteria \#3: Recreation (Service)

\begin{tabular}{|l|l|l|l|}
\hline Dam Name & $\begin{array}{l}\text { Annual \# of Visitation } \\
\text { Days in 2016 }\end{array}$ & $\begin{array}{l}\text { Rank \#1-13 (High- } \\
\text { Low Service) }\end{array}$ & $\begin{array}{l}\text { Rubric Score } \\
\text { (0 to 3) }\end{array}$ \\
\hline Big Cliff & N/A & $\# 13$ & 0.00 \\
\hline Blue River & 27,000 & $\# 11$ & 0.06 \\
\hline Cottage Grove & 80,000 & $\# 9$ & 0.19 \\
\hline Cougar & 189,000 & $\# 6$ & 0.45 \\
\hline Detroit & 749,000 & $\# 2$ & 1.79 \\
\hline Dexter & 200,000 & $\# 5$ & 0.48 \\
\hline Dorena & 26,357 & $\# 12$ & 0.06 \\
\hline Fall Creek & 48,500 & $\# 10$ & 0.12 \\
\hline Fern Ridge & $1,250,000$ & $\# 1$ & 3.00 \\
\hline Foster & 574,000 & $\# 3$ & 1.38 \\
\hline Green Peter & 268,000 & $\# 4$ & 0.64 \\
\hline Hills Creek & 91,800 & $\# 8$ & 0.22 \\
\hline Lookout Point & 95,000 & $\# 7$ & 0.23 \\
\hline
\end{tabular}

Note: * Data from Connolly, 2013; Johnson, 2015; Linn, 2011; Reinhardt, 2017; OPRD, 2017; USFS, 2009; USACE, 2005, 2009, 2015, 2016.

Disregarding Big Cliff Dam (adjacent to Detroit Reservoir), each of the WRBRS structures accommodate recreation. Similar to hydropower, the most discernible arrangement of visitation days is into three categories. Based on access, proximity to population centers and USACE sponsored activities, Detroit, Fern Ridge and Foster Reservoirs attract around $70 \%$ of the regions' visitors. Habitat and water quality restoration project help maintain popularity of reservoirs. USACE works in collaboration with ODFW, local governments and environmental groups to adapt to changing conditions and maintain the popularity of the WRBRS, which helps them promote other operations focused on flood control and hydropower generation (Connolly, 2013). 


\subsection{Fish Mortality}

Table 8. Data for Criteria \#4: Fish Mortality (Disservice)

\begin{tabular}{|l|l|l|l|l|}
\hline Dam Name & $\begin{array}{l}\text { \% Below Dam } \\
\text { Wild } \\
\text { Anadromous Fish } \\
\text { Mortality * }\end{array}$ & $\begin{array}{l}\text { Fish Collection } \\
\text { Facility/Ladder } \\
\text { (Yes or No) }\end{array}$ & $\begin{array}{l}\text { Rank \#1-13 } \\
\text { (Low-High } \\
\text { Disservice) }\end{array}$ & $\begin{array}{l}\text { Rubric Score } \\
\text { (0 to -4.5) }\end{array}$ \\
\hline Big Cliff & $73 \%$ & Yes & \#T-7 & -2.96 \\
\hline Blue River & $28 \%$ & No & $\# 4$ & -1.52 \\
\hline Cottage Grove & $69 \%$ & No & $\# 9$ & -3.49 \\
\hline Cougar & $32 \%$ & Yes & $\# 2$ & -0.73 \\
\hline Detroit & $73 \%$ & Yes & $\# \mathrm{~T}-7$ & -2.96 \\
\hline Dexter & $26 \%$ & Yes & $\# 1$ & -0.41 \\
\hline Dorena & $81 \%$ & No & $\# 12$ & -4.39 \\
\hline Fall Creek & $36 \%$ & Yes & $\# 3$ & -0.95 \\
\hline Fern Ridge & $70 \%$ & No & $\# 10$ & -3.80 \\
\hline Foster & $57 \%$ & Yes & $\# 5$ & -2.09 \\
\hline Green Peter & $83 \%$ & No & $\# 13$ & -4.50 \\
\hline Hills Creek & $53 \%$ & No & $\# 6$ & -2.87 \\
\hline Lookout Point & $80 \%$ & No & $\# 11$ & -4.34 \\
\hline
\end{tabular}

Note: * Data from Connolly, 2013; ODFW, 2007; Sharpe, 2013; Tetra Tech, 2013; USACE, 2011, 2013, 2015; USFS, 2009; Willamette, 2015.

Basin-wide data for anadromous fish depletion is inconsistent due to the challenges in comprehensive record keeping over long time periods. Multiple variables can be considered, including several sub-species, juvenile or adult mortality, below or above dam calculations, hatchery or wild fish, etc. (USFS, 2009). ODFW, USACE, USFS, and other organizations with management roles have compiled Environmental Impact Assessments (EIAs) that provide access to datasets for official analyses (USACE, 2013). An amalgam of EIAs in the WRBRS yields consistent estimates for percentage of wild, adult, anadromous below dam fish mortality. Each tributary has seen declines in their f2ish runs, the majority of which are more than $50 \%$ population losses. 
5.5 Water Temperature Hazards

Table 9. Data for Criteria \#6: Water Temperature Hazards (Disservice)

\begin{tabular}{|l|l|l|l|l|}
\hline Dam Name & $\begin{array}{l}\text { \# Days Above } \\
18.0^{\circ} \mathrm{C}(2016)\end{array}$ & $\begin{array}{l}\text { Elevation } \\
\text { (meters) }\end{array}$ & $\begin{array}{l}\text { Rank \#1-13 } \\
\text { (Low-High } \\
\text { Disservice) }\end{array}$ & $\begin{array}{l}\text { Rubric Score } \\
\text { (0 to -4.5) }\end{array}$ \\
\hline Big Cliff & 0 & $369 \mathrm{~m}$ & \#T-1 & 0.00 \\
\hline Blue River & 32 & $415 \mathrm{~m}$ & $\# 8$ & -1.15 \\
\hline Cottage Grove & 49 & $246 \mathrm{~m}$ & $\# 9$ & -1.76 \\
\hline Cougar & 0 & $518 \mathrm{~m}$ & \#T-1 & 0.00 \\
\hline Detroit & 0 & $482 \mathrm{~m}$ & \#T-1 & 0.00 \\
\hline Dexter & 71 & $214 \mathrm{~m}$ & $\# 12$ & -2.56 \\
\hline Dorena & 66 & $264 \mathrm{~m}$ & $\# 11$ & -2.38 \\
\hline Fall Creek & 55 & $256 \mathrm{~m}$ & $\# 10$ & -1.98 \\
\hline Fern Ridge & 125 & $116 \mathrm{~m}$ & \#13 & -4.50 \\
\hline Foster & 0 & $214 \mathrm{~m}$ & $\# \mathrm{~T}-1$ & 0.00 \\
\hline Green Peter & 0 & $279 \mathrm{~m}$ & \#T-1 & 0.00 \\
\hline Hills Creek & 0 & $472 \mathrm{~m}$ & $\# \mathrm{~T}-1$ & 0.00 \\
\hline Lookout Point & 31 & $287 \mathrm{~m}$ & $\# 7$ & -1.12 \\
\hline
\end{tabular}

Note: * Data from USGS (Water), 2017; USGS (Current), 2017.

The varied distribution of hazardous temperature-days highlights reservoirs with disproportionately high daily mean sums exceeding the EPA threshold of $18.0^{\circ} \mathrm{C}$, which applies to lower-mid sections of river basins based on a seven-day moving average (EPA, 2017). Gaging station results have some correlation with elevation, but also are influenced by pool depth, fill and drawdown schedule, and surrounding topography. Fern Ridge, as the leader in this disservice, is supported by literature discussing this reservoir's issues with temperature, turbidity, and algae blooms (ODFW, 2007). Several dams yielded zero hazardous days, indicating that USACE has controlled temperature with some success, but inconsistently. Certain tributaries yield higher averages, notably the Middle and Coast Fork Willamette. Further analysis can gather data during several years to identify temperature trends indicating if conditions are improving or declining. 


\subsection{Structural Risk}

Table 10. Data for Control Variable: Structural Risk (Control Variable)

\begin{tabular}{|l|l|l|l|}
\hline Dam Name: & Dam Age * & $\begin{array}{l}\text { Rank (\# High to } \\
\text { Low) }\end{array}$ & $\begin{array}{l}\text { Structural Risk } \\
\text { (Hazard Level) }\end{array}$ \\
\hline Big Cliff & 64 years & $\# \mathrm{~T}-4$ & Extreme \\
\hline Blue River & 48 years & $\# 13$ & High \\
\hline Cottage Grove & 75 years & $\# 2$ & High \\
\hline Cougar & 53 years & $\# 9$ & High \\
\hline Detroit & 64 years & $\# \mathrm{~T}-4$ & High \\
\hline Dexter & 63 years & $\# \mathrm{~T}-6$ & High \\
\hline Dorena & 68 years & $\# 3$ & High \\
\hline Fall Creek & 51 years & $\# 10$ & High \\
\hline Fern Ridge & 76 years & $\# 1$ & Extreme \\
\hline Foster & 49 years & $\# \mathrm{~T}-11$ & Moderate \\
\hline Green Peter & 49 years & $\# \mathrm{~T}-11$ & Moderate \\
\hline Hills Creek & 56 years & \#8 & High \\
\hline Lookout Point & 63 years & $\# \mathrm{~T}-6$ & Extreme \\
\hline
\end{tabular}

Notes: * Data from NID, 2016. Dam Risk: Red=Extreme; Orange=High; Green=Moderate.

The NID database categorizes the majority of USACE structures as either high or extreme structural risk. An amalgam of factors (age, construction materials, seismic studies, proximity to towns) determine this metric (NID, 2016). USACE has invested in upgrades on certain spillways and complied with periodic evaluations. However, the recent wave of fifteen-year seismic studies found that the WRBRS is vulnerable to numerous collapses in case of an event along the Cascadia Subduction Zone (AP, 2013).

USACE has invested in an Emergency Action Plan (EAP) system for each WRBRS dam. This is common for federal structures and alleviates risk levels to an extent (NID, 2016) However, based on the designations, serious hazards remain despite this measure, which reduces human risk, yet does not reduce risk potential for the structures themselves, which consistently increase as they age (Nuccitelli, 2017). 
5.7 Synthesis of Overall Service Levels for WRBRS Structures

Table 11. Data for Overall Rubric Scores

\begin{tabular}{|c|c|c|c|c|}
\hline Dam Name & $\begin{array}{l}\text { Cumulative } \\
\text { Rubric Score }\end{array}$ & Ranking (\#1-13) & $\begin{array}{l}\text { Average Overall } \\
\text { Rank }\end{array}$ & Ranking (\#1-13) \\
\hline Big Cliff & -2.51 & $\# 10$ & 8.0 & \#T-9 \\
\hline Blue River & -1.38 & $\# 7$ & 7.6 & \#T-7 \\
\hline Cottage Grove & -3.97 & $\# 11$ & 8.6 & $\# 11$ \\
\hline Cougar & 1.80 & $\# 2$ & 3.8 & $\# 2$ \\
\hline Detroit & 2.94 & $\# 1$ & 3.2 & $\# 1$ \\
\hline Dexter & -2.11 & $\# 9$ & 7.6 & \#T-7 \\
\hline Dorena & -5.00 & $\# 13$ & 9.4 & $\# 13$ \\
\hline Fall Creek & -1.80 & $\# 8$ & 8.0 & \#T-9 \\
\hline Fern Ridge & -4.99 & $\# 12$ & 8.8 & $\# 12$ \\
\hline Foster & 0.17 & $\# 4$ & 5.0 & $\# 4$ \\
\hline Green Peter & -0.94 & \#6 & 6.0 & \#6 \\
\hline Hills Creek & -0.05 & $\# 5$ & 4.2 & $\# 3$ \\
\hline Lookout Point & 0.77 & $\# 3$ & 5.4 & $\# 5$ \\
\hline
\end{tabular}

The final rubric scores comprise the final service and disservice metrics.

Cumulative rubric score is calculated by adding the sum of cumulative service and disservice scores (i.e. $1.62+2.49+1.79=5.9$ for Detroit services and $-2.96+0.00=$ -2.96 for Detroit disservices $=2.94$ cumulative rubric score) . The average overall rank is calculated based on the mean ranking of the structures for each criterion (i.e. $4+2+2+$ $7+1=16 \div 5=3.2$ overall rank for Detroit Dam). These two metrics allow for the comparison of scoring method validity for each of the WRBRS structures.

The general demarcation is whether the dam yields positive or negative results. Nine of the 13 dams have sub-zero scores, suggesting that USACE has been unsuccessful thus far at upgrading structures, adjusting flows to facilitate healthy aquatic habitats and minimize temperature imbalance. Meanwhile, the capacity to increase service level 
is limited. The Dorena Dam hydroelectric project has the potential to improve the benefits of this lowest scoring structure (USACE, 2016). However, its capability will be far less than the three, high power producing structures, which coveys that USACE might reconsider priorities and focus on mitigating the disservices that currently impact the riparian ecosystem around Dorena and other negative scoring structures. The three largest dams (Detroit, Green Peter and Lookout Point) score positively, indicating that despite byproducts, the highest service structures function as the core of the WRBRS. 


\section{Chapter 6: Discussion}

Considering the feasibility of the WRBRS structures, the average score is -1.31 (calculated from sum of cumulative scores $\div 13$ ), representing socioeconomic and environmental and implications of the dams as a composite entity. Also, the relationship between the rubric scoring method and the average ranking score are quite similar, with a few slight variations, suggesting that the integrity of the data analysis methods works effectively for evaluating the WRBRS. Removal of five structures yields a positive overall result for the remaining dams, notably eliminating structures with high fish mortality, compounded by summer temperatures above $18.0^{\circ} \mathrm{C}$. Only two of the five low scoring structures generate hydropower, and none are among the high priority flood regulators. Visual distribution of the criteria is illustrated following continued results discussion.

A valid counterargument can be made that the criteria ought not to be weighed equally, since for example, flood control saves millions in damages, while recreation is an unnecessary, albeit popular use of the reservoirs. The utility of these criteria is not to attempt to include every possible evaluation measure or to attempt to weigh these based on a measure of importance. Instead, it is based on analysis of the most relevant services and disservices for this particular study area, which can provide a framework and tools for continued study by hydrologists, biologists, engineers, economists and other actors to further evaluate dam-influenced watersheds (Rapp 2015). Additional caveats include annual variation in dam management and environmental conditions. For example, yearly temperatures are not static, nor is discharge, which influences hydroelectric capacity. Multi-year data collection and analysis can enhance the scope of 
the study. Nonetheless, associated literature and USACE records support the accuracy of the 2016 water-year as an adequate representation of the service and disservice levels of WRBRS structures, especially for the focal point of this study, which focuses on general metrics to interpret the significance of results rather than micro-scale variations (Connolly, 2013; Thieman, 2007; USACE, 2005, 2016, 2017; USGS, 2017).

The financial benefits of maintaining dams influence management bodies. Yet, when habitat conservation is considered in conjunction with other benefits, the case for removal can out-weigh reasons for maintaining a dam (Quiñones, 2015). Structures that are the only obstruction on their channel, such as Dorena and Fern Ridge, could see great restorative success upon removal, based watershed studies that estimate optimized removal strategies can revive 35-37.2\% channel connectivity (Branco, 2014).

Finally, the role of structural risk as a control variable is focused on validating the rubric score and ranking based scoring method. Based on the results table, there doesn't seems to be a consistent correlation between dam risk and a lower service level. A primary challenge for this component of analysis in the WRBRS is that all of the structures have at least a moderate risk level and the majority of the structures are high risk, making it difficult to find distinct patterns. That said, the utility of this control factor can be maintained as a final calibration of overall service for structures that score notably low or high, and therefore useful in determining whether removal or rehabilitation is a better option as structural risk becomes an increasingly dire issue.

The following section displays the scoring rubric criteria results for each structure in a spider chart (Figures $2.1-2.14$ ), which allows for a visual distribution of 
services and disservices to identify anomalous criteria or WRBRS structures. The final chart (Figure 2.14) is a cumulative graph that depicts the overall average scores of each criterion. The utility of this format of result presentation is that is conveys areas that are disproportionately positive or negative, which can help management bodies determine future operation schemes at individual dams, or throughout the watershed.

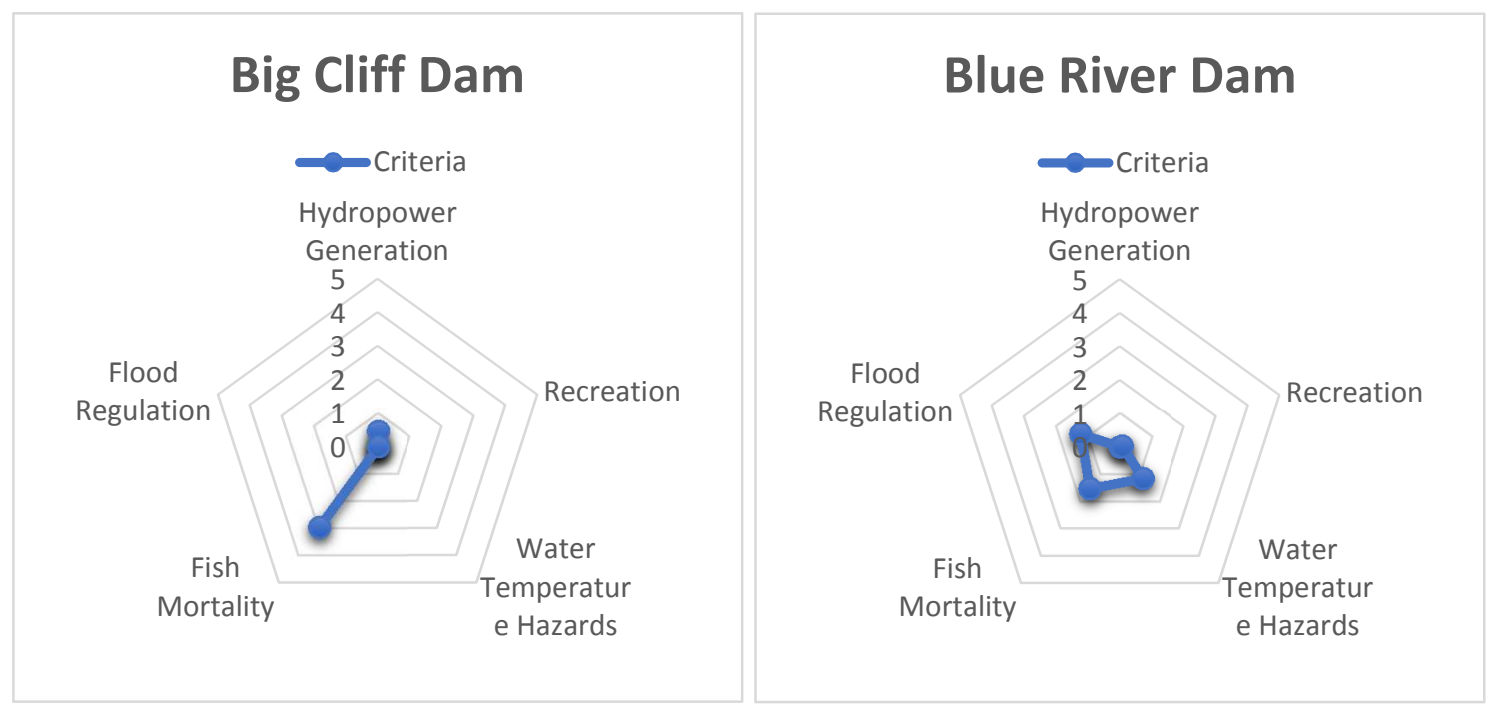

Figure 2.1.

Figure 2.2

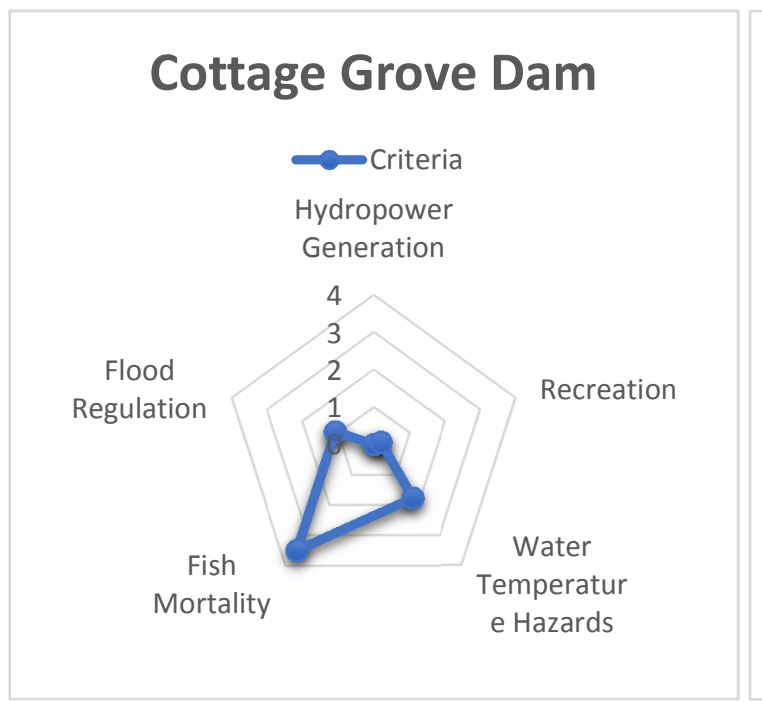

Figure 2.3.

\section{Cougar Dam}

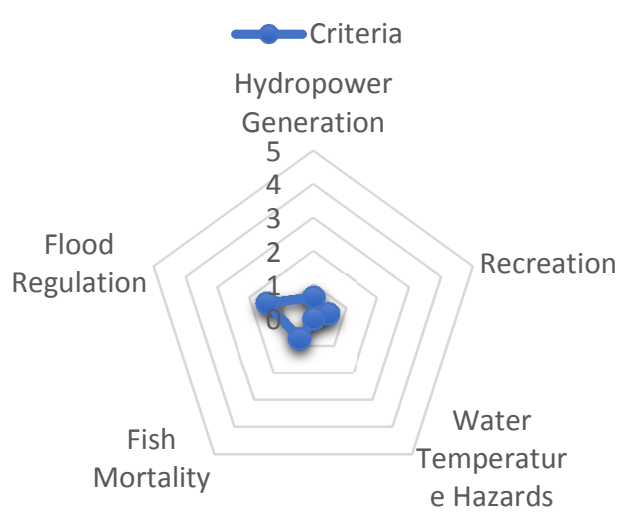

Figure 2.4 


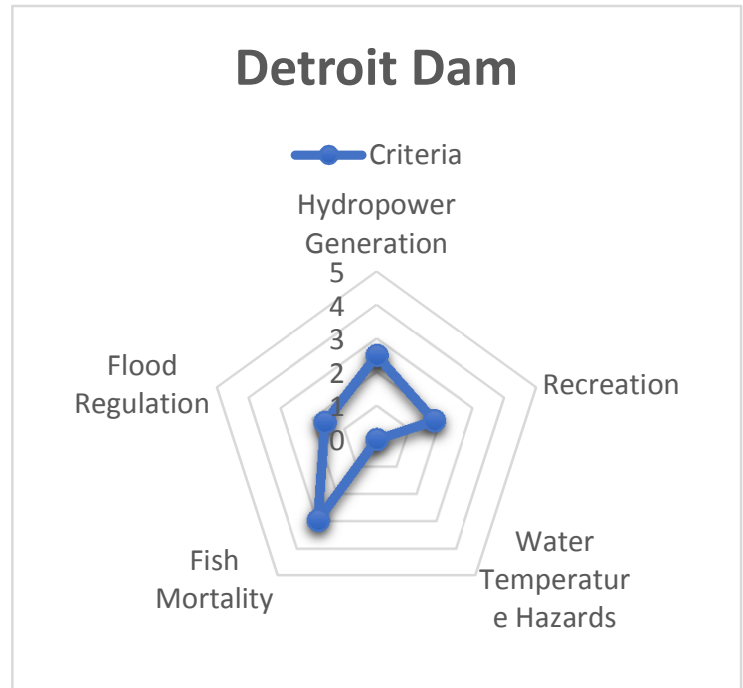

Figure 2.5

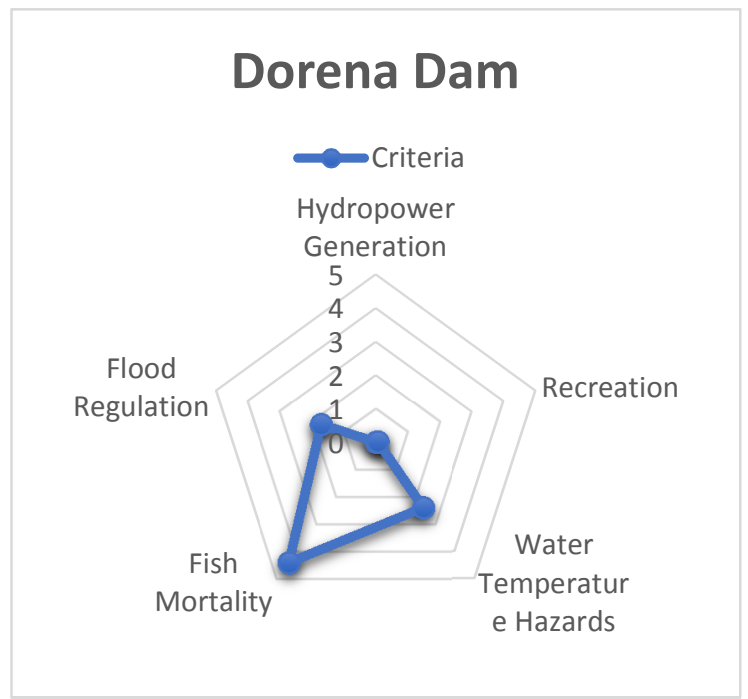

Figure 2.7.

\section{Dexter Dam}

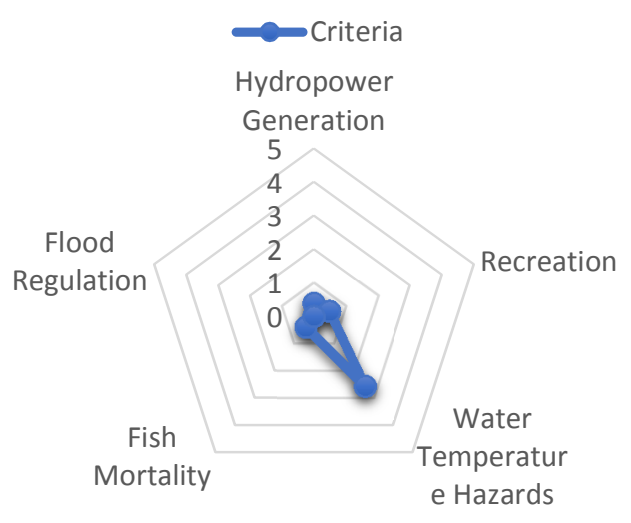

Figure 2.6

\section{Fall Creek Dam}

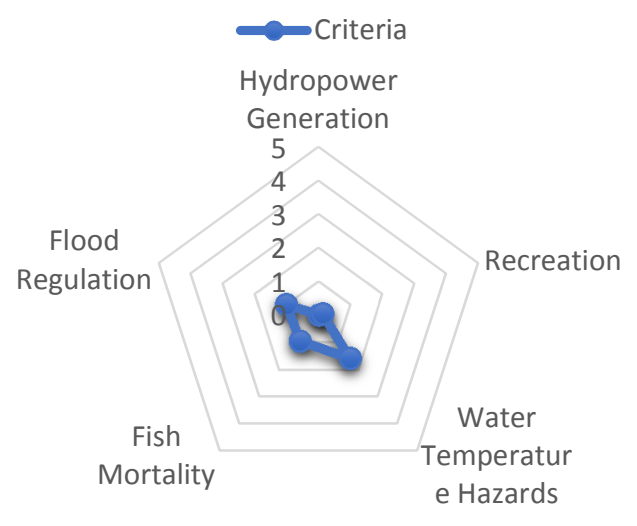

Figure 2.8 


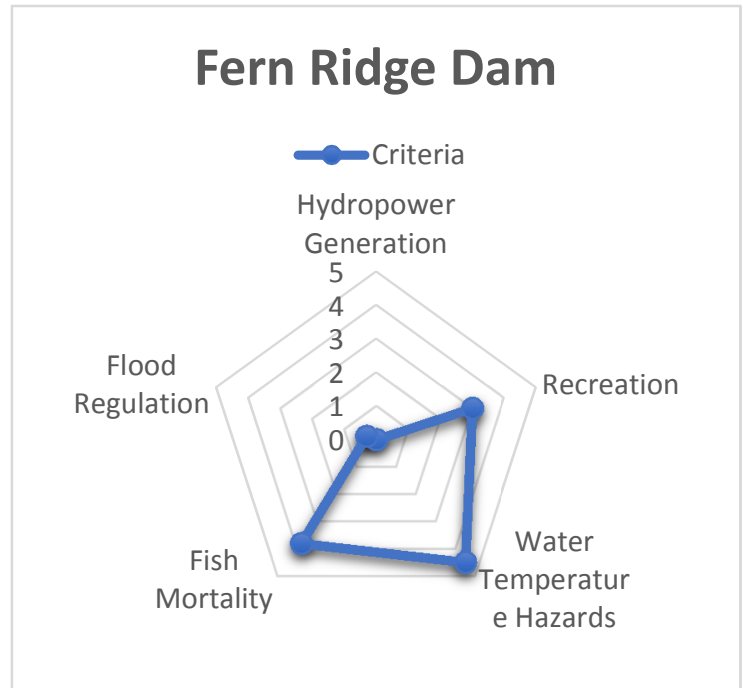

Figure 2.9.

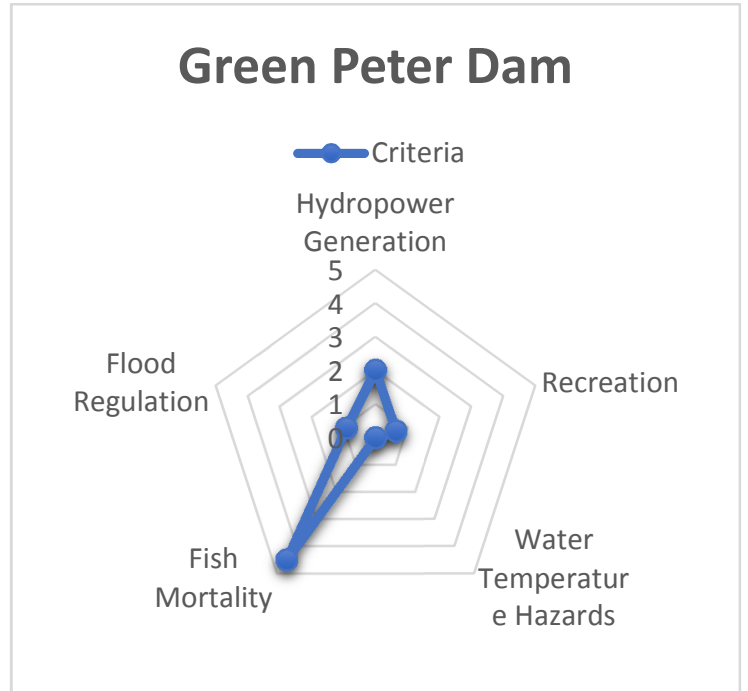

Figure 2.11

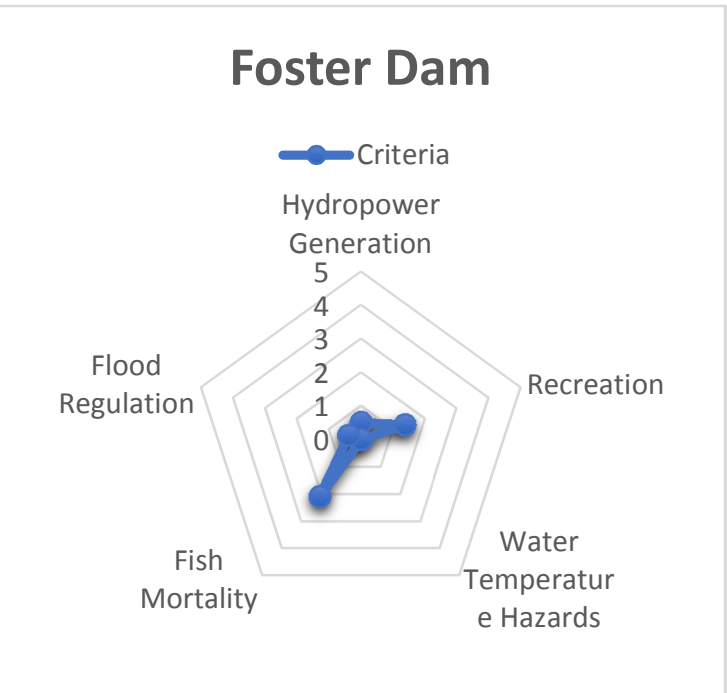

Figure 2.10

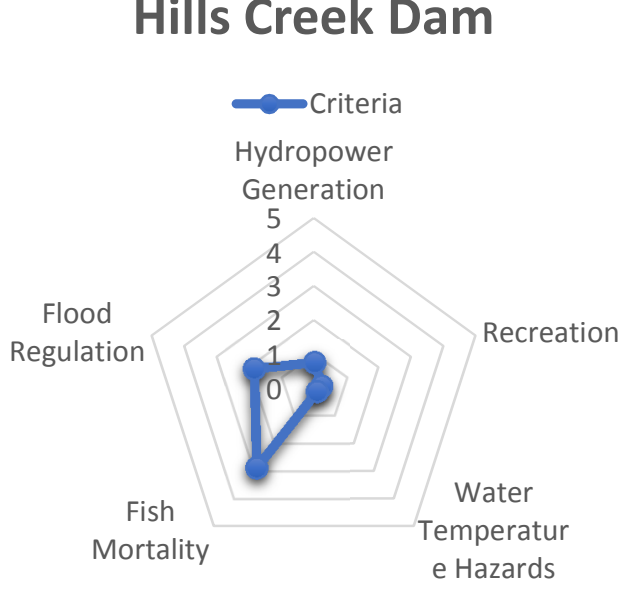

Figure 2.12 


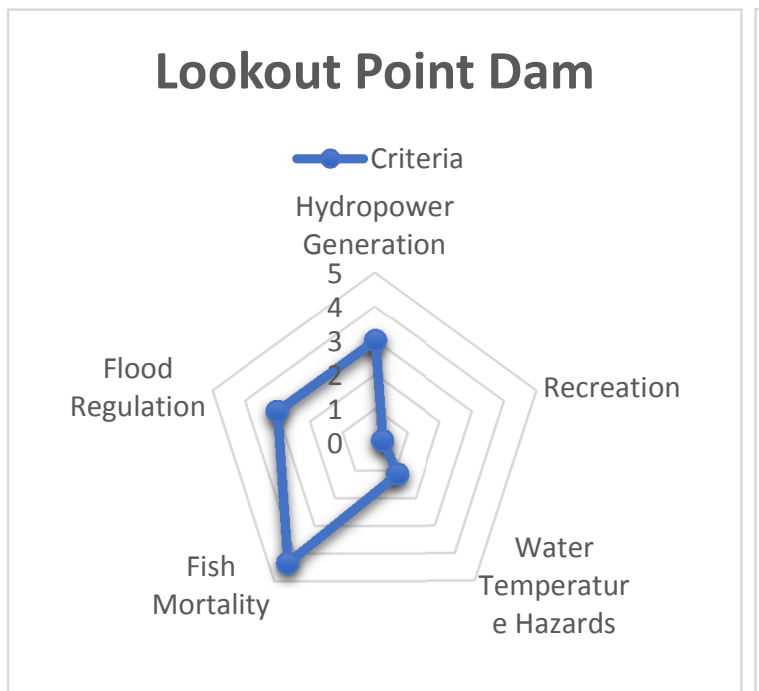

Figure 2.13

\section{Overall Average Scores}

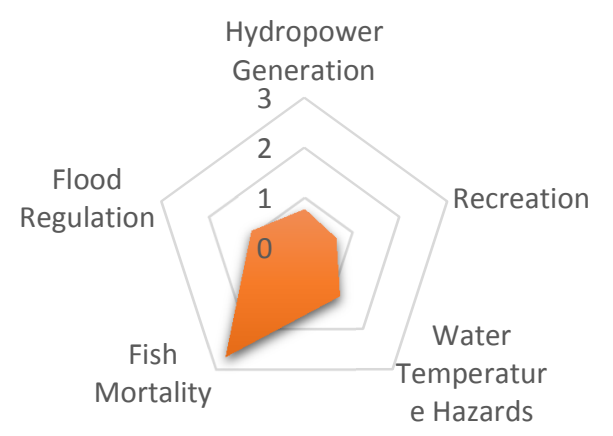

Figure 2.14

Data Sources for Figures 2.1 - 2.14: Atlas, 2017; Connolly, 1992, 2013; Johnson, 2015;

Linn, 2011; NID, 2016; ODFW, 2007; ODWR, 1998; OPRD, 2017; Reinhardt, 2017;

Scherer, 2016; Sinclair, 2015; Tetra Tech, 2013; USACE, 2005, 2009, 2015, 2016, 2017;

USFS, 2009; USGS, 2017.

The final figure (2.14), which depicts the average scores of the WRBRS dams for each criterion, conveys clear management issues faced by USACE. This spider chart is skewed downward towards the disservices and highlights that fish mortality and structural vulnerability are pronounced basin-wide threats. USACE has programs that respond to these disservices, but unless greater investment and innovation takes place, these criteria will deteriorate further (Quiñones, 2015). The flat distribution of service levels stand to benefit from amelioration of disservices, since soundly built structures can regulate floods effectively, and healthy fish populations contribute to recreation and riparian habitat health in general (Gavrilles, 2012). 
The body of knowledge focused on analyzing dam feasibility is expanding quickly, because hydro-scientists understand the urgency in confronting the intensification of structures either currently, or approaching the age range in which environmental impacts and structural hazards commonly outweigh services (Quiñones, 2015). The importance of quantitative reevaluation in this process is evident, because they have had a key role in many of the more than 1,000 dam removal projects, especially the larger-scale decommissionings (Rapp, 2015). The major undammings rely on both preand post-removal analyses, both to carry out the project efficiently and minimize riparian impacts, as well as to develop evaluation methods and datasets that can be applied to future studies (Tomsic, 2007).

Finally, the body of knowledge surrounding actual post-removal riparian habitat successions is growing as the more than 1,000 large dam removal projects are thoroughly documented and studied for a variety of issues that can be contrasted sitespecially based on pre-and post-undamming (American Rivers, 2010). Given the exorbitant expenditures required to carry out a dam decommissioning, and the threats facing a miscalculated project, the resources dedicated to removals are substantial and provide unique insight into the successes and failures in habitat recovery following removal. Studies range in scope and often look at channel geomorphic change or fish repopulation upstream (East, 2015). Importantly, there doesn't seems to be a direct link between structural risk and level of success in decommissioning. That said, as aging structures are analyzed seismically and architecturally, and may prove to be vulnerable in certain cases, having templates for removal projects with similar conditions can be a 
valuable tool for determining whether to engage in a removal project or to restore and continue managing a dam structure (Magilligan, 2016).

This analysis is informed by ideological and methodological principles common to the discipline of hydrology. However, the paradigm for determining each criterion, and the specific evaluation methods are unique to this watershed. Therefore, it offers both a continuation of the ideological progression of dam studies, as well as a novel set of statistics for analyzing a watershed studied exhaustively at a site-specific scale, yet scarcely assessed in terms of the comparative service and disservice levels between each of its basin management components. The relationship between structural vulnerability and dam service is tenuous at best. However, when looking at low performing structures, the risk factor is an integral first step in identifying whether removal or restoration is a more viable option, since some structures despite their age or risk, continue to have important roles in the watersheds they inhabit (USACE, 2016). 


\section{Chapter 7: Conclusions}

The WRBRS provides vital services to the Willamette Valley. Without this comprehensive flood management program, towns would be at high risk for flooding (Sinclair, 2005). The dams also have a legacy of providing electricity to communities and facilitating recreation, all of which have financial value (USACE, 2016). However, the concurrent disservices identified for the WRBRS indicate that these structures also detract from the ecological health of the watershed (Rapp, 2015). This study's results support the concept of diminishing returns that is consistently corroborated in hydroscience. The overall negative score for the WRBRS is impacted most consequently by alarmingly detrimental conditions caused by antiquated dams, notably Cottage Grove, Dorena and Fern Ridge, which yield high disservice levels across the board, corroborated by a high structural risk level. USACE has the autonomy to manage the WRBRS and respond to environmental issues as they see fit (Wyant, 2012). That said, the results of this study suggest that select undammings or intensive restoration to reduce the magnitude of disservice has greater capacity to benefit the system than increasing service levels, which are already near peak capacity.

Despite the omnipresence of dams, their lifespans are finite. As functions reduce and structures deteriorate, all dams ultimately face removal or reconstruction. This is uniquely magnified in the United States, where thousands of semi-centennial or older structures are staged to face obsolescence in unprecedented numbers. Thus, periodic evaluation using site-relevant criteria is "a worthwhile exercise. As dams decline in economic value, the benefits of removal increase" (Quiñones 2015). The 
legacy of positive ecological successions following removal projects thus far supports the conclusion that "there is a strong need for more quantitative studies" that apply comprehensive datasets to analyze dam feasibility (Poff, 2005). 


\section{References}

Allen, Richard. 2001. "Solutions to Critical Habitat Problems in the Columbia Basin." Washington Department of Fisheries. Columbia River Fisheries Project for the Pacific Northwest Regional Commission.

American Rivers. 2010. "Dam slated for removal in 2010." American Rivers, Washington, DC. U.S.A

Angilletta, Jr., Michael J., E. Ashley Steel, Krista K. Bartz, Joel G. Kingsolver, Mark D. Scheuerell, Brian R. Beckman, and Lisa G. Crozier. 2008. "Big dams and salmon evolution: changes in thermal regimes and their potential evolutionary consequences." Evolutionary Applications 1, no. 2: 286-299.

Associated Press (AP). 2013. "Army Corps of Engineers Studies Threat of Quakes to Oregon, Southwest Washington Dams. The Oregonian. April 1, 2013.

Associated Press (AP). 2017. "Army Corps of Engineers Considers Privatizing Some Oregon Hatcheries." The Oregonian. February 7, 2017.

Atlas of Oregon Lakes. 2017. "Atlas of Oregon Lakes and Reservoirs." Center for Lakes and Reservoirs. Oregon Department of Environmental Quality. http://aol.research.pdx.edu/

Avery, Bonnie. 2014. "Willamette Basin Dams and Revetments." Oregon Explorer Natural Resources Digital Library. Oregon State Libraries and Press and Institute for Natural Resources.

Branco, Paulo, Pedro Segurado, José M. Santos, and Maria T. Ferreira. 2014. "Prioritizing barrier removal to improve functional connectivity of rivers." Journal of Applied Ecology 51, no. 5: 1197-1206.

Clean Energy Authority (CEA). 2010. "Energy Facts and Resources." http://www.cleanenergyauthority.com/solar-energy-resources/what-is-amegawatt-and-a-megawatt-hour/

Connolly, Patrick, Mark Wade, James Hutchinson and Jeffrey Ziller. 1992. "Coast Fork Willamette Subbasin Fish Management Plan." Oregon Department of Fish and Wildlife 1-41.

Connolly, Patrick, Mark Wade, and Hutchinson James. 2013. "Long Tom Subbasin Fish Management Plan." Oregon Department of Fish and Wildlife (1992): 1-32. 
Cui, Yantao. John Wooster, Christian Braudrick, Bruce Orr. 2014. "Lessons Learned from Sediment Transport Model Predictions and Long-Term Postremoval Monitoring: Marmot Dam Removal Project on the Sandy River in Oregon." Journal of Hydraulic Engineering 140, no. 9: -1.

East, Amy E., George R. Pess, Jennifer A. Bountry, Christopher S. Magirl, Andrew C. Ritchie, Joshua B. Logan, and Patrick B. Shafroth, et al. 2015. "Reprint of: Largescale dam removal on the Elwha River, Washington, USA: River channel and floodplain geomorphic change." Geomorphology 246, 687-708. Academic Search Premier.

Environmental Protection Agency. 2017. "EPA Issues Final Water Temperature Guidance." Region 10: Oregon. https://www3.epa.gov/region10/pdf/water/temperature_standards_fs.pdf

Esri, DeLorme, HERE, TomTom, Intermap, increment P Corp., GEBCO, USGS, FAO, NPS, NIRCAN, GeoBase, IGN, Kadaster NL, Ordinance Survey, Esri Japan, METI, Esri China (Hong Kong), swisstopo, MamyIndia, and the GIS User Community. 2017. "Topographic Basemap."

Evans, Melissa L., Marc A. Johnson, Dave Jacobson, Jinliang Wang, Michael Hogansen, Kathleen G. O'Malley, and Eric Taylor. 2016. "Evaluating a multi-generational reintroduction program for threatened salmon using genetic parentage analysis." Canadian Journal of Fisheries Aquatic Sciences 73, no. 5: 844-852.

Flatt, Courtney. 2017. "BPA Stops Wind Power Generation for the First Time in 4 Years." Oregon Public Broadcasting. http://www.opb.org/news/article/bpa-stops-windpower-generation-for-the-first-time-in-4-years/

Foundation for Water and Clean Energy Education (FWEE). 2017. "How a Hydroelectric Project Can Affect a River. http://fwee.org/environment/how-a-hydroelectricproject-can-affect-a-river/

Gavrilles, Beth. 2012. "Fish Have Enormous Nutrient Impacts on Marine Ecosystems, Study Finds." University of Georgia Public Affairs Division. National Science Foundation. https://news.uga.edu/releases/article/fish-enormous-nutrientimpacts-121112/

Grasso, Michael. 2015. “U.S. Seek Spillway Gate Rehab at Oregon's Blue River Dam.” Hydroword.com. PenWell Corporation.

http://www.hydroworld.com/articles/premium-content/2015/07/u-s-seeksspillway-gate-rehab-at-oregon-s-blue-river-dam.html 
Jenkins, Jeffrey S. 2011. "The Reproduction of the Klamath Basin: Struggle for Water in a Changing Landscape." Yearbook of the Association of Pacific Coast Geographers 73, 69-78.

Johnson, Daniel, Richard Lycan, and Peterson, Richard, 1985. Eds. Atlas of Oregon Lakes. Corvallis, OR: Oregon State University Press. Revised and Updated 2015.

Kruzic, Lance and Taylor, Barbara. 2008. "Willamette River Fish Recovery." National Oceanic and Atmospheric Administration: West Coast Fisheries.

Kuby, Michael J., William F. Fagan, Charles S. ReVelle, and William L. Graf. 2005. "A multiobjective optimization model for dam removal: an example trading off salmon passage with hydropower and water storage in the Willamette basin." Advances in Water Resources 28, no. 8: 845-855.

Linn County Parks and Recreation. 2011. "Recreation Plan for Green Peter Reservoir and the Quartzville Recreation Corridor." Bureau of Land Management. Oregon Department of Forestry. http://www.linnparks.com/wpcontent/uploads/2016/02/GPRecPlanfinal draftwithMap110811.pdf

Magilligan, F.J., K.H. Nislow, B.E. Kynard, and A.M. Hackman. 2016. "Immediate changes in stream channel geomorphology, aquatic habitat, and fish assemblages following dam removal in a small upland catchment." Geomorphology 252, 158170. Academic Search Premier, EBSCOhost.

Megerian, Chris. 2017. "Will the Crisis at Oroville Dam Become a Catalyst for Change?" Los Angeles Times. February 7, 2017. http://www.latimes.com/politics/la-polsac-oroville-dam-crisis-change-catalyst-20170217-story.html

Mortenson, Eric. 2015. “Ag's Need from Willamette Basin's Dam, Reservoir System Studied." Capital Press: The West's Ag Website.

Nikiforuk, Andrew. 2016. "Debunking Dams." Alternatives Journal (A|J) - Canada's Environmental Voice 42, no. 1: 72.

National Inventory of Dams (NID). 2016. “Corps Map: National Inventory of Dams (Oregon)." United States Army Corps of Engineers. http://nid.usace.army.mil/cm_apex/f?p=838:3:0::NO::P3_STATES:OR 
National Oceanic and Atmospheric Administration (NOAA). 2017. "Willamette River Biological Option. NOAA Fisheries: West Coast Region.

http://www.westcoast.fisheries.noaa.gov/fish_passage/willamette_opinion/inde x.html

Nuccitelli, Dana. 2017. "Expect to See More Emergencies Like Oroville in a Hotter World." The Guardian: Climate Consensus. February, 20. 2017.

Oregon Department of Fish and Wildlife (ODFW). 2007. "Fern Ridge Wildlife Area Management Plan" ODFW Executive Summary, p. 1-39.

Oregon Department of Water Resources (ODWR). 1998. "Willamette Basin Reservoirs: An Overview of US Army Corps Dams and Reservoirs on Willamette River Tributaries." https://www.oregon.gov/owrd/docs/1998_04_Willamette_Brochure.pdf

Oregon Emergency Management Division. 2016. "Hazards and Preparedness." http://www.oregon.gov/oem/hazardsprep/Pages/Cascadia-SubductionZone.aspx

Oregon Parks and Recreation Department (OPRD). 2017. "Fall Creek State Recreation Area." http://oregonstateparks.org/index.cfm?do=parkPage.dsp_parkHistory\&parkld=1 76

Oregon State University \& the State of Oregon. 2017. "Oregon Spatial Data Library." Oregon State University Libraries and Press, Oregon Explorer and Institute for Natural Resources.

Pejchar, L., and Warner, K. 2001. "A river might run through it again: Criteria for consideration of dam removal and interim lessons from California." Environ. Manage., 28(5), 561-575.

Poff, N. L., and Hart, D. D. 2002. "How dams vary and why it matters for the emerging science of dam removal." Bioscience, 52(8), 659-668.

Postel, S.L. 1998. "Water for Food Production: Will There Be Enough in 2025?" Bioscience 48. 629-637.

Quiñones, Rebecca, Theodore Grantham, Brett Harvey, Joseph Kiernan, Mick Klasson, Alpa Wintzer, and Peter Moyle. 2015. "Dam removal and anadromous salmonid (Oncorhynchus spp.) conservation in California." Reviews in Fish Biology \& Fisheries 25, no. 1: 195-215 
Rapp, Valerie. 2015. "The River Fix: Dam Removal Isn't Simple. Neither are Rivers." Oregon Humanities. Spring 2015. 22-27 pp.

Robbins, William. 2017. "Willamette Valley." The Oregon Encyclopedia. Portland State University and the Oregon Historical Society.

Reinhardt, Bob. 2017. "Detroit Dam.” The Oregon Encyclopedia. https://oregonencyclopedia.org/articles/detroit_dam/\#.WMIYYJFHahB

Reisner, Marc. 1986. "Cadillac Desert: The American West and Its Disappearing Water." Revised and updated. Penguin Books, 1993. New York: Viking. N.Y. U.S.A. 564 pp.

Rosenburg, David, Patrick McCully, and Catherine M. Pringle. 2000. Global-Scale Environmental Effects of Hydrological Alterations: Introduction. BioScience 50(9): 746-751.

Saulters, Oral S. 2014. "Undam It? Klamath Tribes, Social Ecological Systems, and Economic Impacts of River Restoration." American Indian Culture \& Research Journal 38, no. 3: 25-53.

Scherer, Laura, and Stephan Pfister. 2016. "Hydropower's Biogenic Carbon Footprint." Plos ONE 11, no. 9: 1-11.

Schreck, Carl. 2012. "Survival of Migrating Salmon Smolts in Large Rivers with and Without Dams. Plos Biology 6.10: 2101-2108.

Sharpe, Cameron, et al. 2013. "Work Completed for Compliance with the 2008 Willamette Project Biological Opinion, USACE funding." Oregon Department of Fish and Wildlife Upper Willamette Research, Monitoring, and Evaluation. 1-126.

Sinclair. 2005. "Flooding and Change on the Willamette River." University of Oregon Scholars Bank 1-8.

<https://scholarsbank.uoregon.edu/xmlui/bitstream/handle/1794/3645/fl oodingwillamette.pdf?sequence $=1>$.

Tetra Tech Inc. 2013. "Willamette River Floodplain Restoration Study Draft Integrated Feasibility Report/ Environmental Assessment" Lower Coast and Middle Fork Willamette River Subbasins. U.S. Army Corps of Engineers Portland District. 1207.

Thieman, C, 2007, Stream Health and Water Quality in the Long Tom Watershed: 1999 - 2006, Long Tom Watershed Council 
Thornthwaite, C.W., and Mather, J.R. 1955. "The water balance." Centerton, N.J., Laboratory of Climatology. Publications in Climatology, v. 8, no. 1, p. 1-104.

Tomsic, Christopher A., Timothy C. Granata, Ryan P. Murphy, and Constance J. Livchak. 2007. "Using a coupled eco-hydrodynamic model to predict habitat for target species following dam removal." Ecological Engineering 30, no. 3: 215-230.

United States Army Corps of Engineers (USACE). 2005. "Willamette River Temperature: McKenzie River Subbasin, Oregon." Technical Appendices. U.S. Army Corps of Engineers Portland District

United States Army Corps of Engineers. 2009. "Cottage Grove Lake and Dorena Lake Oregon." U.S. Army Corps of Engineers Portland District.

http://www.nwp.usace.army.mil/Portals/24/docs/pubs/pamphlets/CottageGrov eDorena.pd

United States Army Corps of Engineers (USACE) Portland District and Oregon Water Resources Department. 2011. "Small-Scale Water Supply Allocation Process Willamette River Basin." State of Oregon.

https://www.oregon.gov/owrd/docs/2011_01_Small_Scale_White_Paper.pdf

United States Army Corps of Engineers (USACE). 2013. “Draft Environmental Assessment Downstream Fish Enhancement for Juvenile Salmonids at Hills Creek, Fall Creek, and Cougar Dams 2013-2020." USACE Portland District. 1-71.

United States Army Corps of Engineers (USACE). 2015. "Fern Ridge Dam and Lake." U.S. Army Corps of Engineers, Columbia Basin Water Management Division. http://www.nwd-wc.usace.army.mil/report/frn.htm

United States Army Corps of Engineers: Portland District. 2016. Willamette Valley Project.http://www.nwp.usace.army.mil/Locations/Willamette-Valley/

United States Army Corps of Engineers (USACE). 2017. “Portland District Hydropower Mission." http://www.nwp.usace.army.mil/Missions/Hydropower/

United States Geologic Survey (USGS). 2017. "Water-Year Summary for USA.” U.S. Department of the Interior. waterdata.usgs.gov 
United States Geologic Survey (USGS). 2017. "USGS Current Conditions for Oregon." U.S. Department of the Interior. Oregon Water Data Maintainer. https://waterdata.usgs.gov/or/nwis/current?

United States Congress. 1960. "Rivers and Harbors Act of 1960." $86^{\text {th }}$ Congress, H.R. 7634. pp 20. https://www.fws.gov/habitatconservation/Omnibus/R\&HA1960.pdf

United States Forest Service (USFS). 2009. “Final Environmental Impact Statement: Land and Resource Management Plan for Willamette National Forest Service." United States Department of Agriculture Pacific Northwest Region.

Wilkinson, Charles. 1992. "Crossing the Next Meridian: Land, Water and the Future of the West." Island Press. Washington D.C.

Willamette Basin Watershed Councils. 2015. "Watershed Summaries: Prepared for the Oregon Watershed Enhancement Board." Biosystems Consulting and Watershed Initiatives.https://www.oregon.gov/OWEB/docs/pubs/rest_priorities/Willamette _watershed_council_summaries_dec05.pdf

Wyant, Jamie. 2012. "The Detroit and Big Cliff Dams: Present Day Management of River Flow." North Santiam Watershed Council. http://northsantiam.org/the-detroitand-big-cliff-dams/

Zheng, Pearl Q., and Benjamin F. Hobbs. 2013. "Multiobjective Portfolio Analysis of Dam Removals Addressing Dam Safety, Fish Populations, and Cost." Journal of Water Resources Planning \& Management 139, no. 1: 65-75. 